Article

\title{
The Potential and Challenges of Using Soil Moisture Active Passive (SMAP) Sea Surface Salinity to Monitor Arctic Ocean Freshwater Changes
}

\author{
Wenqing Tang ${ }^{1, *}$, Simon Yueh ${ }^{1}$, Daqing Yang ${ }^{2}$, Alexander Fore ${ }^{1}$, Akiko Hayashi ${ }^{1}$, Tong Lee ${ }^{1}$, \\ Severine Fournier ${ }^{1}$ (D) and Benjamin Holt ${ }^{1}$ \\ 1 Jet Propulsion Laboratory, California Institute of Technology, Pasadena, CA 91109, USA; \\ Simon.H.Yueh@jpl.nasa.gov (S.Y.); Alexander.Fore@jpl.nasa.gov (A.F.); \\ Akiko.K.Hayashi@jpl.nasa.gov (A.H.); tlee@jpl.nasa.gov (T.L.); Severine.Fournier@jpl.nasa.gov (S.F.); \\ Benjamin.M.Holt@jpl.nasa.gov (B.H.) \\ 2 Environment and Climate Change Canada, Water and Climate Impacts Research Centre, \\ Victoria, BC V8P 5C2, Canada; daqing.yang@canada.ca \\ * Correspondence: Wenqing.Tang@jpl.nasa.gov; Tel.: +1-818-354-8199
}

Received: 5 May 2018; Accepted: 28 May 2018; Published: 4 June 2018

Abstract: Sea surface salinity (SSS) links various components of the Arctic freshwater system. SSS responds to freshwater inputs from river discharge, sea ice change, precipitation and evaporation, and oceanic transport through the open straits of the Pacific and Atlantic oceans. However, in situ SSS data in the Arctic Ocean are very sparse and insufficient to depict the large-scale variability to address the critical question of how climate variability and change affect the Arctic Ocean freshwater. The L-band microwave radiometer on board the NASA Soil Moisture Active Passive (SMAP) mission has been providing SSS measurements since April 2015, at approximately $60 \mathrm{~km}$ resolution with Arctic Ocean coverage in 1-2 days. With improved land/ice correction, the SMAP SSS algorithm that was developed at the Jet Propulsion Laboratory (JPL) is able to retrieve SSS in ice-free regions $35 \mathrm{~km}$ of the coast. SMAP observes a large-scale contrast in salinity between the Atlantic and Pacific sides of the Arctic Ocean, while retrievals within the Arctic Circle vary over time, depending on the sea ice coverage and river runoff. We assess the accuracy of SMAP SSS through comparative analysis with in situ salinity data collected by Argo floats, ships, gliders, and in field campaigns. Results derived from nearly 20,000 pairs of SMAP and in situ data North of $50^{\circ} \mathrm{N}$ collocated within a $12.5-\mathrm{km}$ radius and daily time window indicate a Root Mean Square Difference (RMSD) less than $\sim 1$ psu with a correlation coefficient of 0.82 and a near unity regression slope over the entire range of salinity. In contrast, the Hybrid Coordinate Ocean Model (HYCOM) has a smaller RMSD with Argo. However, there are clear systematic biases in the HYCOM for salinity in the range of 25-30 psu, leading to a regression slope of about 0.5 . In the region North of $65^{\circ} \mathrm{N}$, the number of collocated samples drops more than 70\%, resulting in an RMSD of about 1.2 psu. SMAP SSS in the Kara Sea shows a consistent response to discharge anomalies from the $\mathrm{Ob}^{\prime}$ and Yenisei rivers between 2015 and 2016, providing an assessment of runoff impact in a region where no in situ salinity data are available for validation. The Kara Sea SSS anomaly observed by SMAP is missing in the HYCOM SSS, which assimilates climatological runoffs without interannual changes. We explored the feasibility of using SMAP SSS to monitor the sea surface salinity variability at the major Arctic Ocean gateways. Results show that although the SMAP SSS is limited to about 1 psu accuracy, many large salinity changes are observable. This may lead to the potential application of satellite SSS in the Arctic monitoring system as a proxy of the upper ocean layer freshwater exchanges with subarctic oceans.

Keywords: SMAP; sea surface salinity; Arctic Ocean; sea ice; river discharge; Arctic Gateways 


\section{Introduction}

The Arctic Ocean is experiencing unprecedented changes: the loss of sea ice [1-3], becoming fresher [4-6] and warmer [7,8], and the intensification of the regional freshwater cycle [9]. The urgency to closely monitor changes in the Arctic freshwater system and its exchange with subarctic oceans has been widely recognized by the scientific communities [10-16] Among the key observables, ocean salinity plays a critical role of linking the freshwater components within the atmospheric, terrestrial, and cryospheric water cycles to ocean circulation [17-23]. In particular, salinity responds to terrestrial runoff (river discharge), sea ice melt and growth, surface freshwater forcing (precipitation and evaporation), and exchanges with subarctic oceans via oceanic transports through Arctic gateways [24]. The Arctic freshwater changes that are associated with salinity alter the horizontal and vertical density structure of seawater, thereby influencing regional oceanic processes with global consequences [25-29].

In situ salinity observations in the Arctic Ocean have been historically very sparse. Spaceborne observation of sea surface salinity (SSS) is anticipated to advance our monitoring capability for the Arctic Ocean. SSS is a good tracer of the freshwater movement in the upper Arctic Ocean. The synoptic large-scale spatial variability of the SSS field that was obtained from the vantage point of space will not only monitor freshwater changes due to regional processes in the Arctic Ocean, but it will also provide a means to improve our understanding of the interaction between the Arctic and subarctic oceans.

Global SSS observations have been available from three satellite missions. The first one is the European Space Agency (ESA) Soil Moisture and Ocean Salinity (SMOS) mission launched on 2 November 2009 [30,31], carrying a passive L-band microwave system. The second one is the Aquarius/SAC-D, a joint venture of National Aeronautics and Space Administration (NASA) and Argentina's Comision Nacional de Actividades Espaciales (CONAE) [32-34], which was in operation from 10 June 2011 to 7 June 2015. The NASA Soil Moisture Active Passive (SMAP) observatory, which was launched in 31 January 2015, designed to measure the soil moisture over land [35], is also observing global ocean with an L-band radiometer and is currently being used to estimate SSS [36].

Satellite SSS data have enabled many new scientific results for tropical and subtropical oceans. However, its applications in the polar and sub-polar oceans did not progress as well due to two reasons $[37,38]$. First, satellite SSS retrieval in high latitude seawater is complicated by several factors. L-band instrument sensitivity to SSS is greatly reduced in cold seawater $[39,40]$. Leakage of emissivity from sea ice into the satellite antenna's main lobe or through the antenna side-lobes can contaminate salinity signals if undetected [41]. The larger uncertainty in the ocean surface roughness correction in the rough seas frequently encountered under the conditions of high winds and the strong waves of polar oceans influences the accuracy of the SSS retrievals [42,43]. The relatively large uncertainties of the ancillary satellite sea surface temperature (SST) data in the Arctic Ocean used in the SSS retrievals also affect the SSS accuracy [44]. Second, the paucity of in situ measurements hinders the validation of satellite SSS [45-47]. The validation of satellite SSS using in situ data can also be complicated by the difference in spatial scale between the satellite measurements over satellite footprints, and the point-wise in situ measurements in regions with strong sub-footprint variability [48-50]. As a result, quite large gaps near land and ice are masked out ( 110 km for Aquarius and $\sim 50 \mathrm{~km}$ for previously released SMAP SSS) in order to avoid contaminated retrieval, which could be misinterpreted or interfere with global validation results.

The recent release of SMAP SSS (V4.0) produced at the Jet Propulsion Laboratory (JPL) [51] was based on a more advanced correction strategy, aiming to deliver the valuable information in the critical regions near land and sea ice as much as possible. One of the main improvements is land contamination correction on measured brightness temperature (TB) before SSS retrievals. Land contamination is the leakage of energy from land surface into the radiometer receiver through side lobes or partially through the main lobe. In land-contaminated TB, non-oceanic signatures mixed with oceanic signatures may result in differences between two categories that exceed 100 kelvin (K). If undetected or uncorrected, the non-oceanic signature would cause large bias in the satellite salinity values. The JPL SMAP SSS 
algorithm has implemented the land contamination correction that is based on two look-up-tables (LUT), both being derived from SMAP data itself. One LUT is the beam-integrated land fraction as a function of footprint position and orientation, while the other is a monthly climatology of land TB extending out to $1000 \mathrm{~km}$ from coast, which represents effective contributions of TB from side-lobes over land. Combining the two LUTs, the land contamination contribution for each SMAP footprint is estimated and removed from TB. With improved land correction, the JPL algorithm retrieves SSS within $35 \mathrm{~km}$ from the land wherever the sea ice concentration values are less than 3\% (based on NCEP SIC analysis [52]).

This study investigates the utility and accuracy of SMAP SSS retrieved in the Arctic Ocean via two complementary approaches: (1) comparing with collocated in situ salinity data, and (2) analyzing the co-variability of SMAP SSS with changes in sea ice and river discharges. We also examined the seasonal and interannual variability of SMAP SSS over major Arctic Ocean gateways to explore the potential of satellite SSS as a proxy to infer the freshwater exchange between the Arctic and sub-oceans. The datasets that were used for the analysis are described in Section 2. The results are presented in Section 3. Section 4 provides further discussion, and Section 5 summarizes the findings.

\section{Data}

\subsection{SMAP SSS}

SMAP SSS are produced at Level 2 (L2) and Level 3 (L3). L2 data represents the spatial average of the instantaneous measurements in the swath footprint, delivered for each of the salinity-wind-cell (SWC) along the satellite swath with $1624 \times 76$ cells along/cross track per satellite revolution. L2 data covers the global ocean in eight days with a spatial resolution of $\sim 60 \mathrm{~km}$, posted on a $25 \mathrm{~km}$ grid. There are two Level 3 (L3) products, the first with monthly temporal averaging and the second with eight-day averaging, both on a global $0.25^{\circ} \times 0.25^{\circ}$ grid. The eight-day product is created daily by averaging eight days of L2 data centered at noon UTC (Coordinated Universal Time) of the day with a search radius of $45 \mathrm{~km}$ and a Gaussian weighting half-power distance of $30 \mathrm{~km}$. Also, provided along with L2 and L3 products are the surface salinity output from the Hybrid Coordinate Ocean Model (HYCOM) [53] interpolated to SMAP measurement time and location.

Currently, there are two SMAP SSS products. One is the JPL product $[36,51]$ that is mentioned in Section 1, and the other is based on algorithm independently developed at the Remote Sensing System (RSS) [54]. Both datasets are available at NASA Physical Oceanography Distributed Active Archive Center (PO.DAAC) (http:/ / podaac.jpl.nasa.gov). The RSS product leaves large gaps in the Arctic Ocean near the ice edge, and is therefore not suitable for this study. We will focus on analyzing the JPL SMAP SSS V4.0 product (hereafter named SMAP SSS).

\subsection{In Situ Salinity Data}

Individual Argo float profiles are obtained from USGODAE (The United States (US) Global Ocean Data Assimilation Experiment, http:/ /www.usgodae.org/argo/argo.html). The Argo array consists of approximately 3700 floats in the global ocean measuring salinity and temperature [55,56]. Argo data were collected and were made freely available by the International Argo Program and the national programs that contribute to it, as part of the Global Ocean Observing System (GOOS).

Salinity data from ships and gliders in the Arctic Ocean are obtained from the Copernicus Marine Environment Monitoring Service (CMEMS), which is an earth observing data center under the European Commission [57]. We use the product of Arctic Ocean-In situ Near Real Time Observations [58], which contains data collected from the Arctic ROOS (Regional Ocean Observing System) members, and quality controlled using automated procedures that are available from the In Situ Thematic Assembly Centre (INS TAC).

We also used data sets that were collected in recent field campaigns. During the NASA Ocean Melting Greenland (OMG) mission $[10,11]$ field campaigns that took place in September/October 
2016 and October 2017, NASA's G-III research plane, flying along the Greenland coast, deployed Airborne expandable CTD (AXCTD) sensors to measure temperature and salinity profiles from the surface to about $1000 \mathrm{~m}$ depth [58]. Quality controlled OMG data is made publicly available at (https://omg.jpl.nasa.gov/portal/). University of East Anglia, UK provided us with the salinity data from the seaglider missions MASSMO4, AlterEco and Oman579 (personal communication with Bastien Queste, PI) (http:/ / ueaglider.uea.ac.uk).

\subsection{Sea Ice Concentration}

Sea ice concentration (SIC) data not only identifies ice-free areas where satellite SSS retrieval is possible, but also may influence the SSS values through freshwater exchanges that were associated with sea ice changes [59]. We obtain the daily and monthly SIC data from the NASA DAAC at the National Snow and Ice Data Center (NSIDC). The SIC data set [NSIDC-0051] is generated from multi-frequency brightness temperature data and is designed to provide a consistent time series of SIC combining the coverage of several passive microwave instruments [60]. The data are provided in the polar stereographic projection at a grid cell size of $25 \times 25 \mathrm{~km}^{2}$. The SIC data are also available in the Near-Real-Time (NRT) with a daily update [61]. The JPL SMAP SSS retrieval algorithm uses the high resolution $\left(1 / 12^{\circ}\right)$ SIC analyses from NCEP [52] to identify ice-free regions (ftp:/ /ftpprd.ncep.noaa. gov/pub/data/nccf/com/omb/prod/). The SMAP L1B TB footprints falling into bins with SIC $<3 \%$ are flagged as ice-free.

\subsection{River Discharge}

Many large rivers in the northern regions produce huge amounts of flow to the Arctic Ocean. River discharge is therefore a dominant component in the Arctic freshwater system. Land hydrology in the polar regions are closely related with climate change and permafrost conditions $[62,63]$. The daily discharge data from six largest Arctic rivers are available from Arctic Great River Observatory (Arctic-GRO) (http:/ / arcticgreatrivers.org), which is a component of the National Science Foundation's (NSF) Arctic Observing Network (AON). Arctic-GRO implemented identical sampling and analytical protocols that were developed by the PARTNERS Project (Pan-Arctic River Transport of Nutrients, Organic Matter, and Suspended Sediments), a coordinated international effort to collect and analyze a time-series of water samples $[64,65]$. We use discharge data from $\mathrm{Ob}^{\prime}$ and Yenisey River during May 2015 to April 2017 for this study [66]. Other studies examined the flow regimes and changes for these two rivers $[67,68]$. We focus on the discharge at the downstream stations for basin freshwater input to the Arctic Ocean.

\subsection{Moorings at Arctic Gateways}

The main Arctic gateways are well monitored by in situ mooring arrays [24,69,70]. The mooring data over the Bering Strait $[69,70]$ was obtained from the Applied Physics Laboratory (APL) at the University of Washington (http:/ / psc.apl.washington.edu/HLD/Bstrait/bstrait.html). Although the measuring depth of moorings $(\sim 50 \mathrm{~m})$ is largely different from the penetration depth $(\sim 1-2 \mathrm{~cm})$ of L-band radiometer, and is therefore is not included in the in situ data for validation (Section 3.1), it should provide an indication of the dynamical range of the seasonal variation and interannual trend of SSS. Historical mooring data also exists at the Davis Strait and the Fram Strait. Unfortunately, we were not able to find up-to-date mooring data at either the Davis Strait or the Fram Strait.

\section{Results}

\subsection{Validation with In Situ Salinity}

We aggregated in situ salinity data collected by Argo floats, ships, gliders, and in OMG field campaigns to create a gridded in situ data set on $0.25^{\circ} \times 0.25^{\circ}$ grids daily from 1 April 2015 to 31 March 2018. Measurements of different instruments, such as CTD (Conductivity, Temperature and 
Depth), XCTD (Expandable CTD), and TSG (Thermosalinograph) taken within $5 \mathrm{~m}$ of the sea surface are used. Figure 1 shows the distribution of in situ measurements North of $50^{\circ} \mathrm{N}$ on $0.25^{\circ}$ grids, as long as there is as least one daily record in three years on the grid point. Areas South of $60^{\circ} \mathrm{N}$ are mostly covered by Argo floats, complemented by a few ship tracks. Areas between $60^{\circ} \mathrm{N}$ and $80^{\circ} \mathrm{N}$ in Greenland area are well covered combining ships, gliders, and OMG data. However, above the Arctic Circle, particularly North of the Bering Strait, there are almost no in situ salinity data.

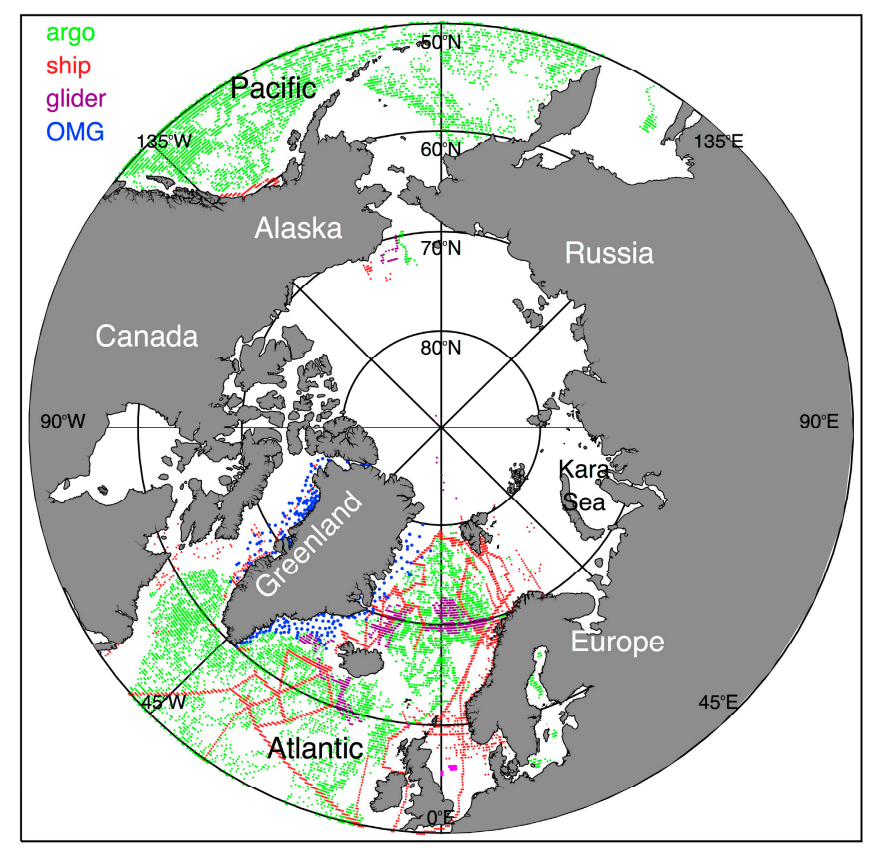

Figure 1. Location where in situ salinity are collected within $5 \mathrm{~m}$ from surface by Argo float (green), ship (red), glider (purple), and OMG AXCTD (blue) during the three years from April 2015 to March 2018.

The three-year mean of SSS averaged over collocated grid points from April 2015 to March 2018 are illustrated in Figure 2. In situ data confirms the large-scale salinity feature that was observed in SMAP SSS, i.e., the much saltier seawater on the Atlantic side than on the Pacific side of the Arctic Ocean. The biases with respect to in situ salinity are less than 1 psu in a majority of the areas, which are masked out in white so areas with large biases stand out more clearly (Figure 2, right column). It can be seen that SMAP SSS shows positive biases in a few places near the coast, and negative biases along the east coast of Greenland and near Davis Strait (Figure 2d). On the other hand, HYCOM SSS shows mostly positive biases east of Greenland (Figure 2e). The contrast between SMAP and HYCOM east of Greenland is particularly interesting. It suggests that SMAP SSS retrieval may contain un-detected sea ice effect, while HYCOM is not able to catch the freshening signal due to ice melting where no Argo floats are available for HYCOM's operational data assimilation.

The statistical results of comparing in situ salinity with collocated SMAP SSS and HYCOM SSS are presented in Table 1 and Figure 3. All data are gridded on $0.25^{\circ}$ grids daily, covering the period from April 2015 to March 2018. North of $50^{\circ} \mathrm{N}$, the bias, standard deviation, and Root Mean Square Difference (RMSD) between 19,738 pairs of SMAP SSS and in situ are 0.442, 2.391 and 2.431 psu with correlation of 0.81 . The statistics between HYCOM SSS and in situ is slightly better. The open circles in the scatter plot indicate outliers defined as those pairs where the absolute difference exceeds three times the standard deviation. The number of such defined outliers is less than $1 \%$ of the total collocated data set. The entire set of collocated data can be visually divided into two groups: one group of high SSS ( $>25 \mathrm{psu})$ and the other of low SSS ( $<10 \mathrm{psu})$. It is interesting to note that in the low SSS group, in situ salinity are distinct at three sub-groups that are centered around 2, 5, and 7 psu, with collocated SMAP SSS spread from 0 to 10 psu, while HYCOM SSS almost perfectly aligned with the in situ data. 
Again, this is expected because most of the in-situ data being used for the evaluation here are from Argo profiling floats, and HYCOM assimilates the Argo float data operationally.
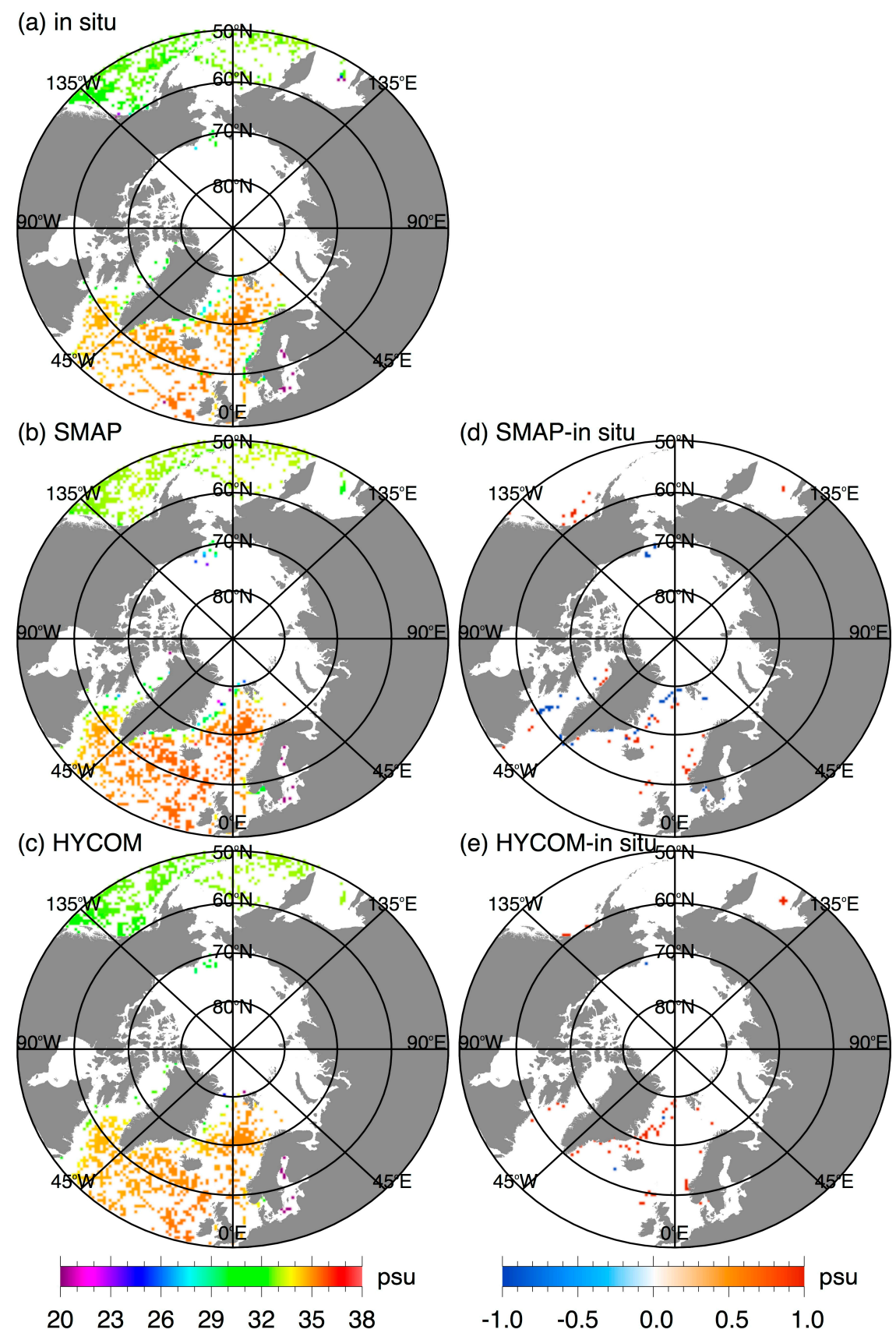

Figure 2. Salinity maps North of $50^{\circ} \mathrm{N}$ averaged from 1 April 2015 to 31 March 2018 from (a) in situ data, (b) Soil Moisture Active Passive Sea Surface Salinity (SMAP SSS), and (c) Hybrid Coordinate Ocean Model (HYCOM) SSS, and the difference of (d) SMAP SSS minus in situ, and (e) HYCOM SSS minus in situ, wherever absolute differences less than 1 psu are masked out in white. 
Table 1. Results of statistical comparison between in situ salinity and SMAP SSS (JPL V4.0) and HYCOM SSS, for North of $50^{\circ} \mathrm{N}$ or North of $65^{\circ} \mathrm{N}$, respectively. All data are gridded on $0.25^{\circ}$ grids averaged daily from April 2015 to March 2018. N is the number of collocated pairs; bias (data minus in situ), standard deviation (Std.) and Root Mean Square Difference (RMSD) are in psu; Corr. stands for the correlation coefficients.

\begin{tabular}{ccccccccccc}
\hline \multicolumn{1}{c}{ North of $\mathbf{5 0 ^ { \circ }} \mathbf{N}$} \\
\hline & $\mathrm{N}$ & Bias & Std. & RMSD & Corr. & N & Bias & Std. & RMSD & Corr. \\
SMAP & 19738 & 0.442 & 2.391 & 2.431 & 0.805 & 5785 & 0.342 & 2.829 & 2.849 & 0.509 \\
HYCOM & 19738 & 0.270 & 2.110 & 2.128 & 0.934 & 5785 & 0.285 & 2.337 & 2.354 & 0.892 \\
\hline & & \multicolumn{4}{c}{ After excluding outliers } \\
SMAP & 19543 & 0.385 & 0.987 & 1.060 & 0.817 & 5712 & 0.339 & 1.179 & 1.227 & 0.518 \\
HYCOM & 19617 & 0.149 & 0.661 & 0.678 & 0.942 & 5749 & 0.182 & 0.840 & 0.860 & 0.900 \\
\hline
\end{tabular}

(a)

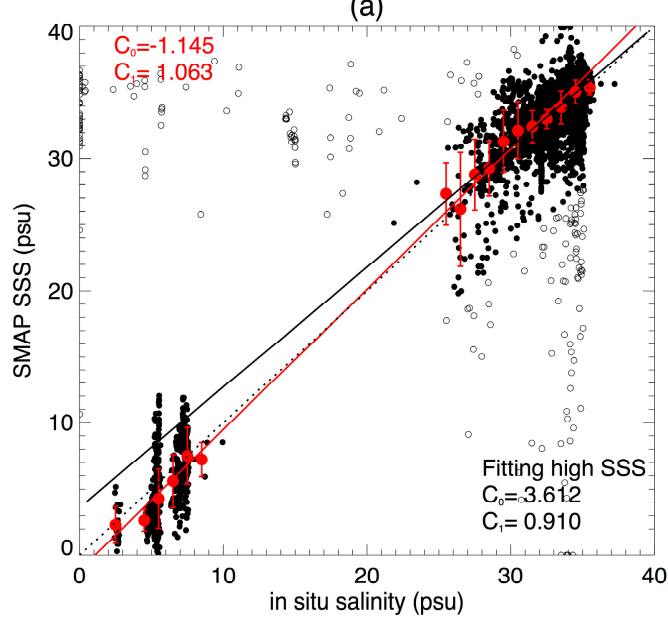

(b)

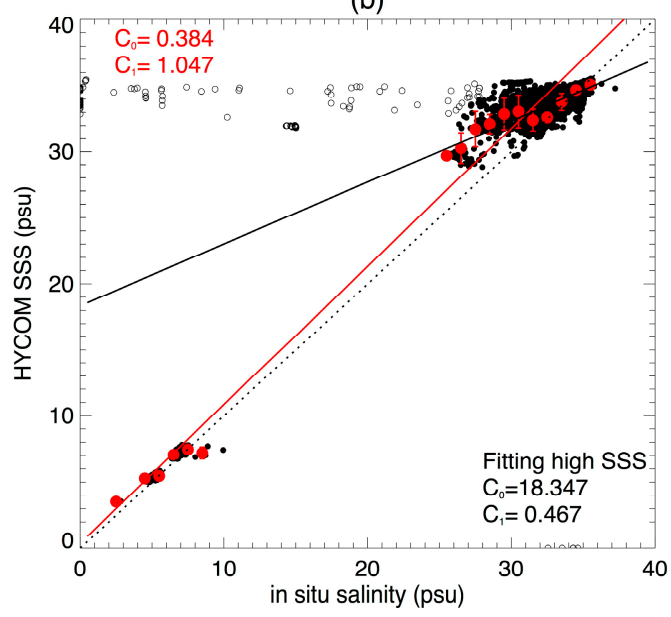

Figure 3. Scatterplot of in situ salinity collected within $5 \mathrm{~m}$ from surface and collocated data of (a) SMAP SSS and (b) HYCOM SSS. Collocations are based on gridded data on $0.25^{\circ}$ grids averaged daily from April 2015 to March 2018. The three clusters associated with low in situ salinity (2-7 psu) are located in the Gulf of Bothania and the Baltic Sea. Open circles indicate where the absolute difference between the pair exceeds three times of the standard deviation. Linear regression of all data (excluding outliers) bin-averaged in terms of in situ SSS (bin size of $1 \mathrm{psu}$ ) is illustrated in red with zero intercepted denote by $\mathrm{C}_{0}$ and slope by $\mathrm{C}_{1}$, while the regression of high SSS (>25 psu, excluding outliers and the low salinity clusters.) is illustrated in black. Red dots indicate bin-average and vertical error bars indicate \pm 1 standard deviation in the bin. Dotted line indicates the diagonal for reference.

Significant outliers of SMAP SSS are seen as being associated with the high SSS group in two branches, with positive and negative biases, respectively, where positive bias may indicate an over estimation of the surface roughness correction, and the negative bias may suggest un-detected ice contamination. This will be considered for the next version of SMAP geophysical model function to improve the SSS retrieval algorithm. Note that there is no negative bias in HYCOM for the high SSS group. However, there is similar positive bias in the HYCOM versus in situ. After excluding the outliers, the bias, standard deviation, and RMSD between 19,543 pairs of SMAP SSS and in situ are $0.385,0.987$, and 1.060 psu with correlation of 0.82 .

North of the Arctic Circle, the number of collocated points drops more than $70 \%$. Table 1 also provides of statistical results North of $65^{\circ} \mathrm{N}$. The bias and RMSD between 5712 pairs of SMAP and in situ after removing outliers are 0.339 and 1.227 psu, respectively.

After excluding the outliers, we performed a linear regression of the SMAP (or HYCOM) vs. in situ data. The regression slope for SMAP is close to 0.9 if only the data for in situ greater than $25 \mathrm{psu}$ are considered (Figure 3). If all data are included, then the regression slope is 1.06. Interestingly, HYCOM 
SSS seems to have a systematic positive bias for in situ SSS in the range of 25 to $30 \mathrm{psu}$, resulting in a reduced regression slope of 0.467 for the high SSS group of data. The SMAP SSS conditioned on the in situ within this range has a smaller bias, although being more noisy.

\subsection{The Arctic Ocean SSS and Sea Ice}

Figure 4 illustrates the monthly mean SSS from 2015 to 2017 in August, when the Arctic Ocean ice has the minimum extent with maximum ice-free surface areas for satellite salinity retrieval. The large-scale salinity feature, i.e., saltier Atlantic and fresher Pacific is consistently observed in three consecutive years and it agrees with the known contrast between the two ocean basins. North of the Arctic Circle $\left(\sim 66^{\circ} \mathrm{N}\right)$, however, SMAP SSS shows large interannual variations, not only in magnitudes of SSS retrieved, but also in areas with a valid retrieval. For example, North of the Bering Strait, in August 2015, SSS is retrieved in the large areas of the Chukchi Sea and the East Siberian seas; in August 2016 in the Beaufort Sea and the East Siberian Sea; and, in August 2017 areas with valid retrieval extended further north in all three marginal seas. This is due to the differing sea ice extent for the same months among three years, because SMAP SSS retrieval is only possible in open water. For the regions with SSS retrieval in all three years, e.g., in the Hudson Bay or Kara Sea, SMAP SSS shows large interannual differences. In contrast, HYCOM SSS shows a much small variation in the marginal seas within the Arctic Circle. It is known that HYCOM uses climatology river discharge and its SSS is relaxed to a seasonal climatology; both may suppress the magnitude of interannual variations of SSS in HYCOM [71].

SMAP SSS in marginal seas near the ice edge often show very low values. These fresh signatures should be examined and validated very carefully because it could be a mixture of real signal and ice contamination. It is known that in seawater near the ice edge, sea ice formation, and melt have significant contributions to the mixed layer salt budget of the ambient waters, with growing importance toward the ice edge [59]. Sea ice concentration (SIC) averaged in the areas North of $65^{\circ} \mathrm{N}$ changes dramatically through the seasonal cycle, from $20 \%$ in October or November to more than $70 \%$ in winter (January-May) (blue curve in Figure 5). It appears that the seasonal cycle of SSS averaged North of $65^{\circ} \mathrm{N}$ closely follows that of SIC, with the lowest SSS being observed within one or two months of the minimum SIC. This covariance should be taken with a grain of salt though, since the low SSS in summer also includes the effect of river runoff, and the high SSS in winter largely comes from the Atlantic side when most marginal seas are frozen. However, it is evident that SMAP SSS (black curve in Figure 5) reveals large interannual variations that are consistent with the sea ice conditions. Note that while averaging of SIC was over the entire region including zero or non-zero SIC values, the averaging of SSS is obtained over ice-free areas, which itself changes with time. We found the ice-free area during the ice melting seasonal peak of 2017 is 5\% and 10\% more than the two previous seasons of 2015 and 2016 (red curves in Figure 5). Correspondingly, the Arctic Ocean averaged SMAP SSS is the lowest in August 2017 despite HYCOM SSS showing essentially no changes. To alienate the possibility that summer SSS minimum was dominated by a few extremely low SSS retrievals or river discharges, Figure 5 also shows the time series of SSS after excluding outliers, which is identified as where the absolute differences from the daily mean exceeding three times of the standard deviation in the averaging domain. After removing the outliers (about 1 to $5 \%$ of valid retrievals of the day), the domain averaged SSS increases by 1-2 psu in its summer low for both SMAP and HYCOM, indicating that most outliers are in the low end of SSS. It is important to note that with outliers removed, SMAP SSS still shows clear interannual variability with minimum of 2017 season more than 2 psu lower than that of 2016, in contrast to HYCOM SSS. The consistent seasonal variation of SSS and SIC suggests that SMAP SSS retrieval correctly characterized the effect of sea ice changes. 

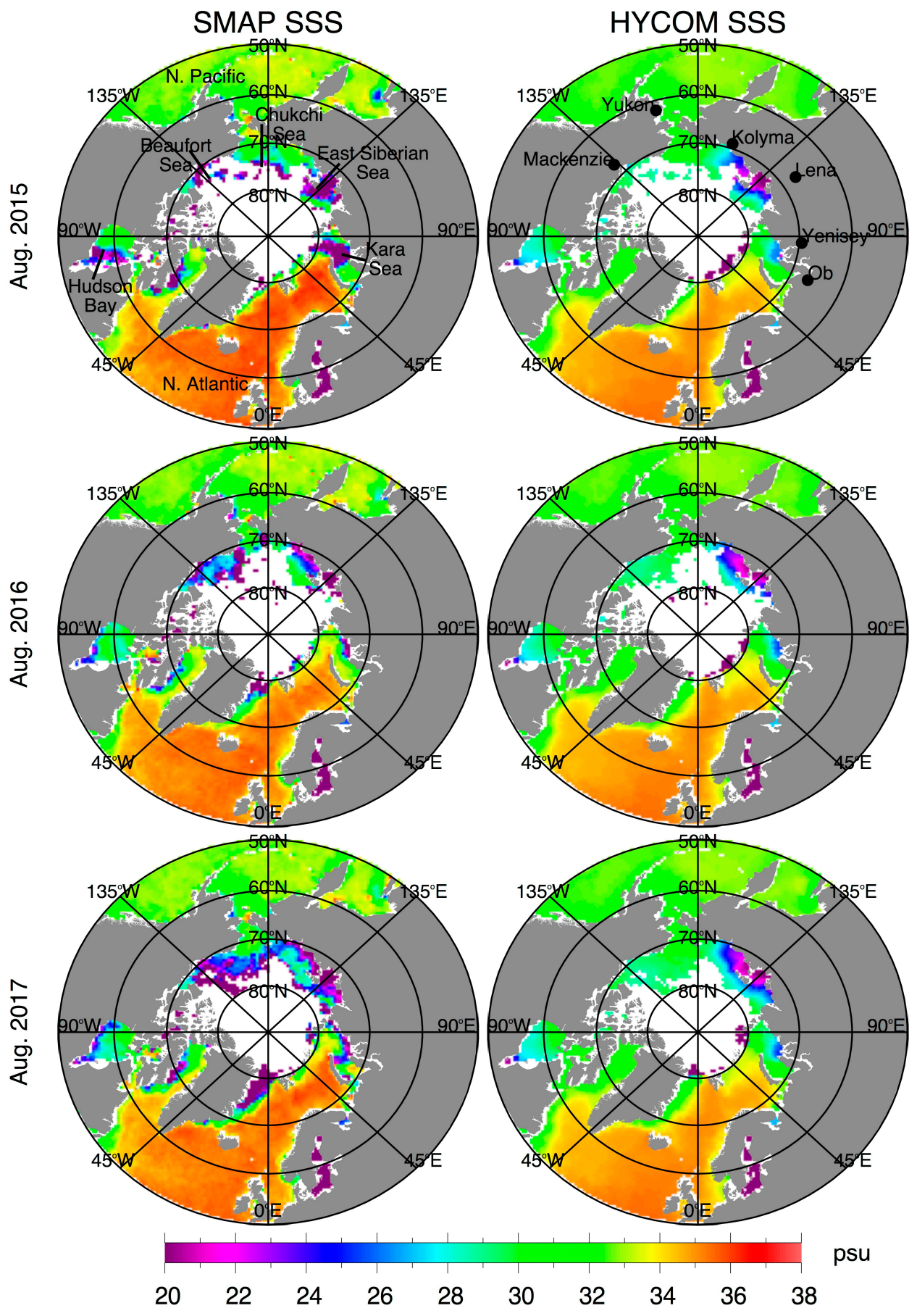

psu

Figure 4. Salinity maps North of $50^{\circ} \mathrm{N}$ from SMAP (left) and HYCOM (right) for the months of August 2015, 2016, and 2017 (top to bottom). Marginal seas are indicated in the top left panel. Black dots in the top right panel indicate locations of river discharge data are collected. 


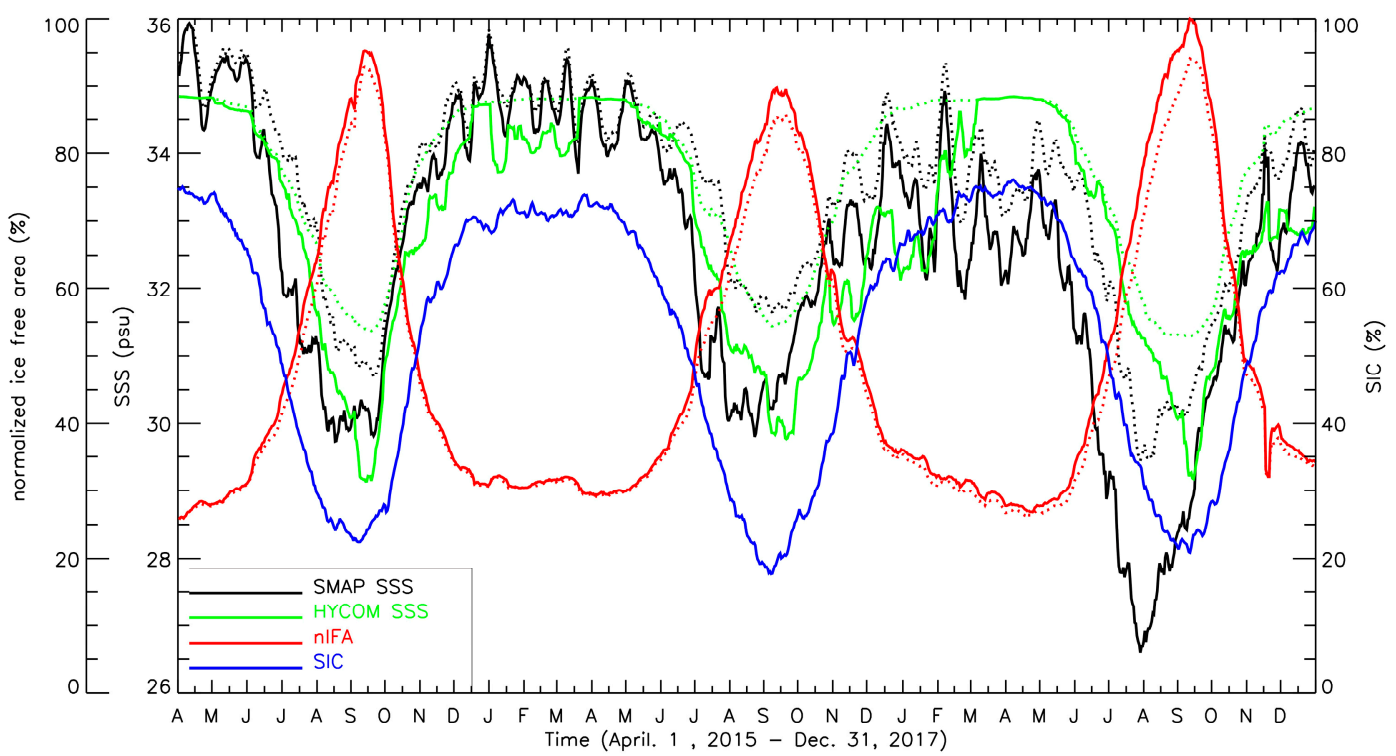

Figure 5. The time series of SMAP SSS (black) and HYCOM SSS (green) averaged in the domain North of $65^{\circ} \mathrm{N}$ in the ice-free-area (red) over all retrievals (solid line), or with outliers removed (dotted line). Outliers are identified as where the absolute differences from the daily mean exceeding three times of the standard deviation ( 1 to 5\%). Ice-free-area is normalized (nIFA) by the record maximum (observed in September 2017). Sea ice concentration (SIC) (blue) is averaged daily North of $65^{\circ} \mathrm{N}$ including zero and non-zero values.

However, this agreement is encouraging but insufficient to completely exclude the effect of un-detected ice-contamination impacting SMAP SSS. The appearance of frazil-pancake ice maybe increasing in the margins of the Arctic during autumn, as identified in a recent field campaign [16]. This type of new sea ice forms in the presence of incoming surface waves and it commonly occurs in the wave-dominated marginal ice zone of the Southern Ocean. With the retreat of the Arctic summer ice edge, the increased fetch has led to the increase of surface waves in the summer and fall, particularly in the Beaufort-Chukchi seas. Frazil-pancake ice may present a challenge to identify, say with passive microwave, as the sea ice concentrations may be quite variable over short time scales, which may lead to contamination in the SSS fields. Frazil-pancake ice has long been identifiable in SAR imagery. One recent study [72] describes the validation of a method to estimate the thickness of this young ice type based on wave dispersion. Being able to identify this form of new ice in the Arctic along with other sea ice conditions (e.g., melt, thin ice thickness, eddy formation, presence of waves) and the extent within the marginal ice zone will improve the accurate detection of ice and reduce the uncertainty in the satellite SSS retrieval.

\subsection{SSS and River Discharge}

As indicated in Section 3.1, there are very few in situ salinity data in the marginal seas within the Arctic Circle; for example, in the Hudson Bay and Kara Sea, no in situ data during the three years of SMAP were identified. In this section, we explore an alternative validation by examining the change of SMAP SSS in response to independently measured river discharge data. Massive northern rivers transport huge quantities of water from the continents to the Arctic Ocean. The freshwater inputs that are associated with river runoff should be reflected in the SSS field, particularly near the river mouths and over the shallow shelf areas. Due to its proximity to the two major Arctic rivers ( $\mathrm{Ob}^{\prime}$ and Yenisey), the Kara Sea provides an ideal case to examine SSS response to river discharge.

Figure 6 illustrates the evolution of SMAP SSS over the Kara Sea for the warm season (May to October) of 2015 and 2016. No SSS were retrieved in the Kara Sea before June and after October because it was completely covered by sea ice. The first valid SSS retrievals appeared in June, but at different 
locations in 2015 and 2016 due to the different spatial coverage of sea ice. The differences between these two years became more dramatic throughout the season. In the summer of 2015, the freshwater patch first appeared in June, in the area east of the northern tip of the Novaya Zemlya archipelago. It grew and spread to cover almost half of the Kara Sea in August. In contrast, in the season of 2016, the freshwater signature was limited to areas near $\mathrm{Ob}^{\prime}$ and Yenisey Bay. Because the whole region has become almost ice-free after July, the impact of new freshwater inputs from sea ice melt is likely to be minimal. Therefore, the dramatic freshening signature spreading through middle of the Kara Sea from July to September in 2015 and along the Siberia coast in 2016, must have originated from the other freshwater source-river discharge. Below, we show that the contrast in SMAP SSS clearly reflects the differences in river runoff in those two years.

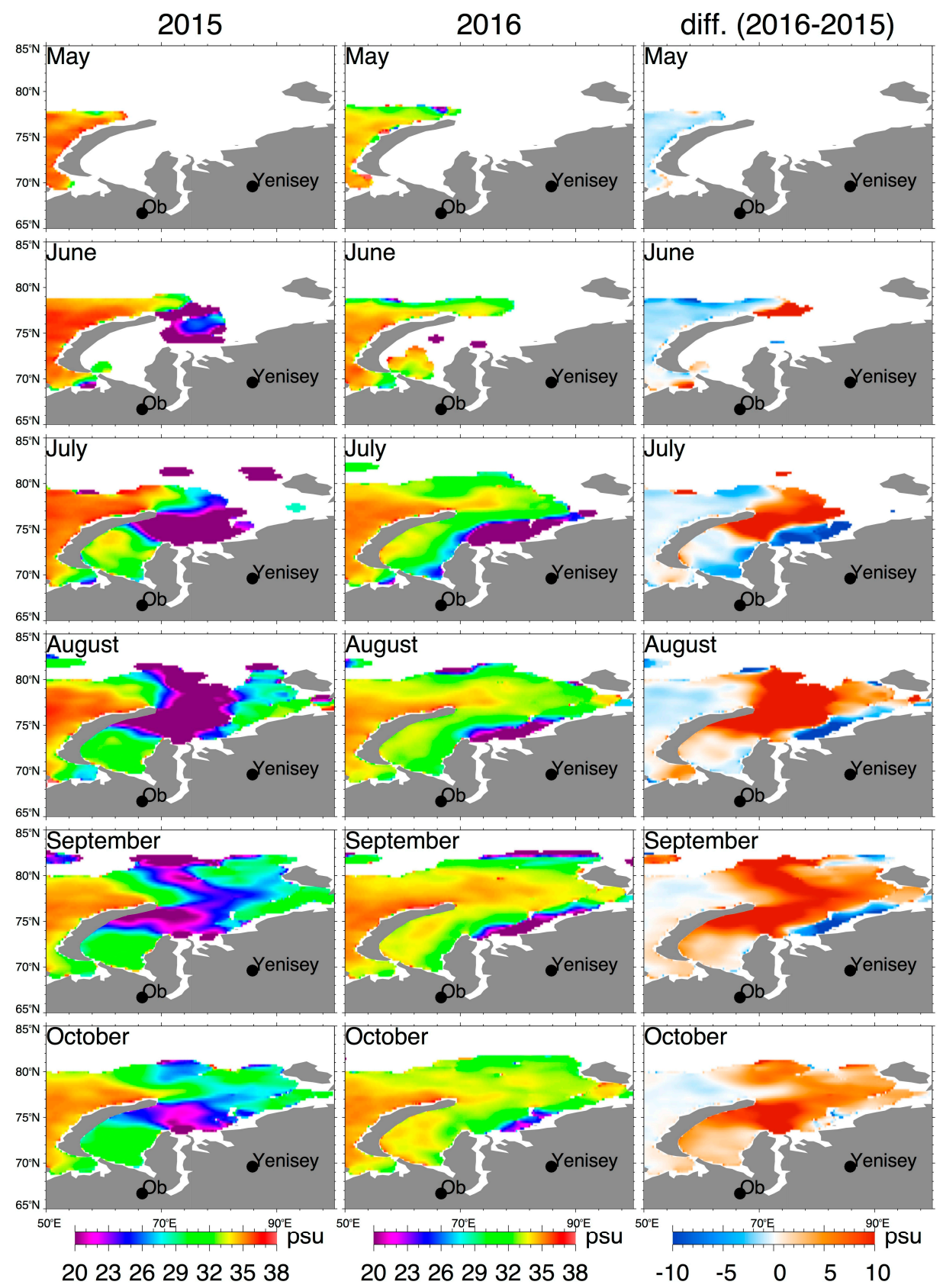

Figure 6. SSS in Kara Sea for the months from May to October (top to bottom) for the year 2015 (left) and 2016 (middle). The corresponding differences (2016 minus 2015) are shown in the right column. Sampling locations of the $\mathrm{Ob}$ and Yenisey River are indicated by black dots. 
As a reference, Figure 7 illustrates the SSS evolving patterns in the Kara Sea from HYCOM SSS. The anomaly in HYCOM SSS is an order of magnitude smaller. As mentioned before, HYCOM is forced by climatological river discharges and its SSS is relaxed to a seasonal climatology [71]. These two climatological forcing would suppress the magnitude of interannual variations of SSS in HYCOM for regions without in-situ data or where in-situ data are insufficient to constraint the model SSS, such as the Kara Sea.

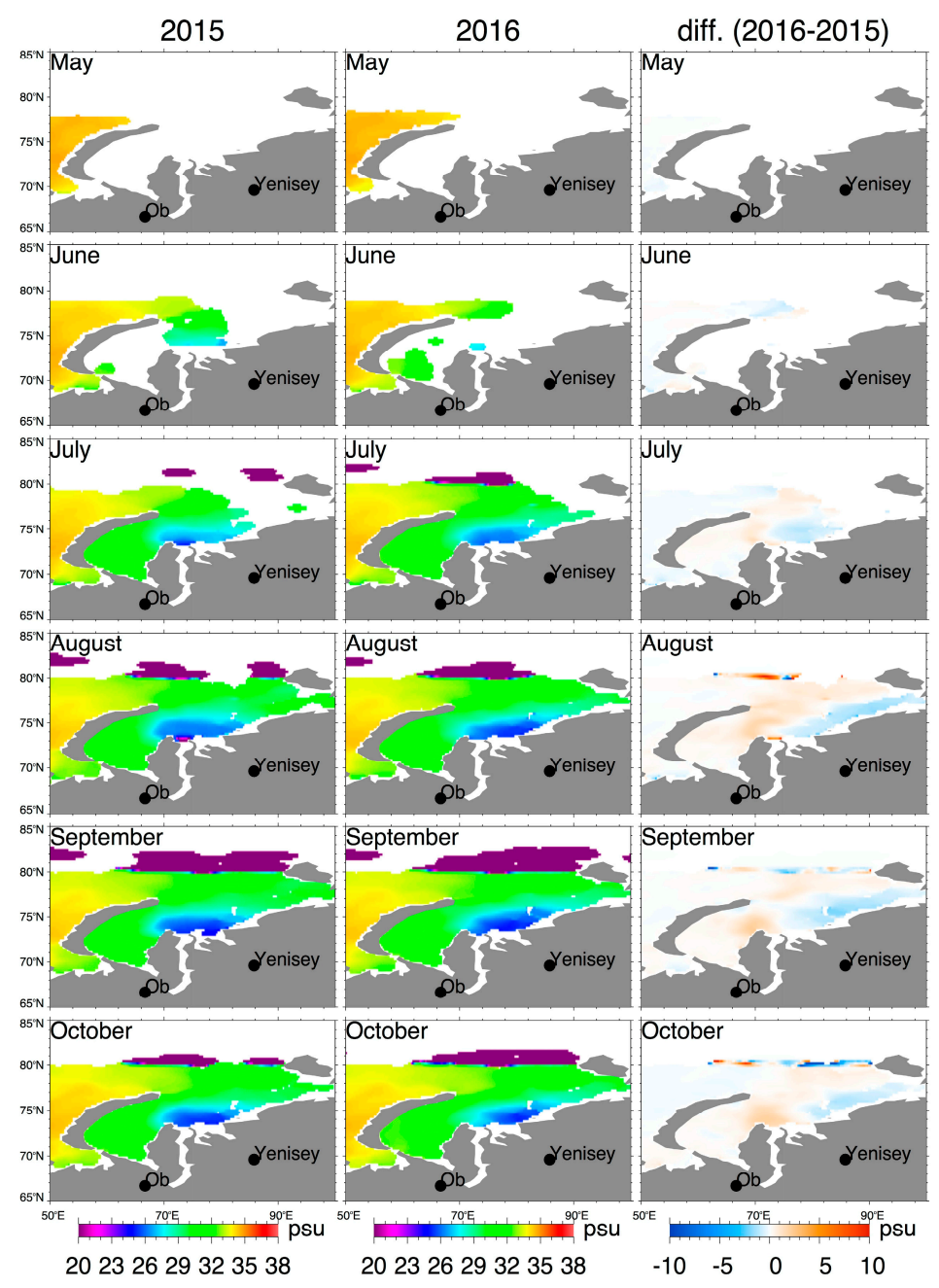

Figure 7. Similar as Figure 6 for HYCOM SSS.

In the surface layer of Kara Sea ocean currents carry waters from the River $\mathrm{Ob}^{\prime}$ and River Yenisey to the north and northeast. Based on the SMAP SSS observations in the Kara Sea (Figure 6), we find that river discharge adjacent to the Kara Sea must be much larger in 2015 than in 2016. The additional freshwater in 2015 was transported northward and further spread along the path, while the spreading of freshwater discharge in 2016 was limited along the coast.

Indeed, the daily discharge data from the $\mathrm{Ob}^{\prime}$ River and the Yenisey River (Figure 8) show differences that are consistent with SMAP observation. In the first two months of the warm season (May and June), discharge from $\mathrm{Ob}^{\prime}$ shows a similar magnitude for the two years, while Yenisey discharge peaked early and injected $93.4 \mathrm{~km}^{3}$ more water in 2015 than 2016 . In the following four months from July to October, $\mathrm{Ob}^{\prime}$ became the main player, putting $90.9 \mathrm{~km}^{3}$ more freshwater into the Kara Sea, while Yenisey added another extra $31.5 \mathrm{~km}^{3}$ (Table 2). Combining the discharges from the $\mathrm{Ob}^{\prime}$ and Yesiney during May to October together, the Kara Sea received more than $210 \mathrm{~km}^{3}$ extra freshwater in 2015 relative to 2016. 

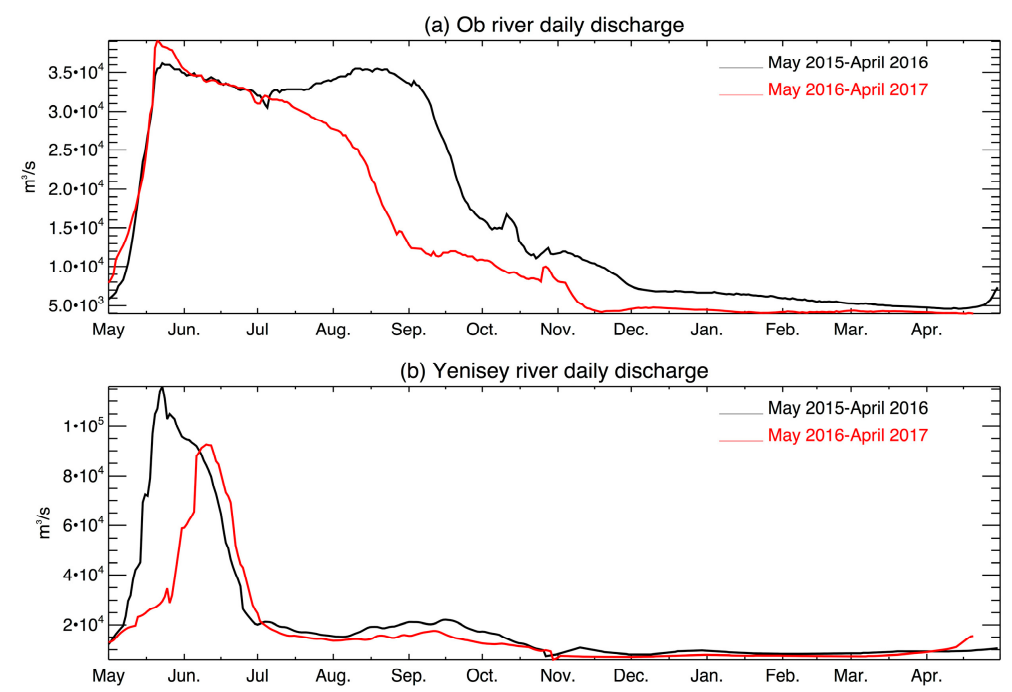

Figure 8. Daily river discharge from (a) Ob' and (b) Yenisey Rivers during May 2015 to April 2016 (black) and from May 2016 to April 2017 (red).

Table 2. Comparison of $\mathrm{Ob}^{\prime}$ and Yenisey River integrated discharge for the warm seasons of 2015 and 2016.

\begin{tabular}{ccccc}
\hline \multirow{2}{*}{ Unit: $\mathbf{k m}^{\mathbf{3}}$} & \multicolumn{2}{c}{ May-June } & \multicolumn{2}{c}{ July-October } \\
\cline { 2 - 5 } & $\mathbf{O b}^{\prime}$ & Yenisey & $\mathbf{O b}^{\prime}$ & Yenisey \\
\hline 2015 & 148.89 & 335.17 & 285.03 & 184.17 \\
2016 & 154.11 & 241.78 & 194.12 & 152.70 \\
$\Delta(2015$ minus 2016) & -5.22 & 93.39 & 90.90 & 31.47 \\
$\Delta$ (Ob' \& Yenisey) & \multicolumn{2}{c}{88.17} & \multicolumn{2}{c}{122.37} \\
\hline
\end{tabular}

It might be useful to roughly estimate the effect of this extra amount of freshwater on the SSS anomaly. About $3 \mathrm{~cm}$ of freshwater are needed to dilute $1 \mathrm{~m}$ of seawater with a change of salinity by 1 psu. Assuming the extra $\sim 210 \mathrm{~km}^{3}$ freshwater spread over half of the Kara Sea (total surface area $\left.926,000 \mathrm{~km}^{2}\right)$, it may produce 15 psu salinity changes within top $1 \mathrm{~m}$ surface water layer, or $7.5 \mathrm{psu}$ within top $2 \mathrm{~m}$. As seen in Figure 6 (right column), the areas with positive SSS differences that are exceeding 10 psu covering about half of the Kara Sea areas, which is in the same order of magnitude as the freshening effect that was possibly produced by the river discharge difference in the two years. It is understood that large differences in SSS anomaly may depend on how the discharge freshwater transported horizontally and vertically, in terms of depth and spread of the diluted water body. Nevertheless, the agreement in order of magnitude is encouraging.

\subsection{SSS Variability at Arctic Ocean Gateways}

We have demonstrated that SMAP SSS retrieves reasonably good quality data in the Arctic Ocean in terms of comparisons with in situ salinity data (Section 3.1) and in response to river discharge (Section 3.3). Here, we further explore the feasibility of using satellite SSS to monitor the surface salinity variability at Arctic Ocean Gateways. We examine if the SSS variability at the gateways are significantly greater than the retrieval accuracy of 1 psu.

The Arctic Ocean exchanges freshwater with the sub-oceans through four major gateways, as shown schematically in the currents map (Figure 9a from Figure 2a in [14]): the Bering Strait inflows of relative fresh Pacific waters; the Barents Sea Opening (BSO) and part of the Fram Strait inflow of the salty Atlantic water; and, through the Davis Strait and the part of the Fram Strait between Greenland and Svalbard, which comprise the major outflow locations of water modified 
by the Arctic Ocean in addition to freshwater that is associated with sea ice flux and subsequent melt $[12,14]$. Because the general directions of the ocean currents at gateways are known, the surface salinity variability observed at the gateways carries the information of the freshwater passing through the regions in the upper ocean.

We first describe the procedure to extract SSS information at each of the Arctic gateways. The exact locations of the gateways defined for this study are given in Table 3 and are indicated in Figure $9 \mathrm{~b}$. To ensure currents flow through the passage in a roughly unique direction, we divided the Fram Strait into two parts: one between east Greenland coast and $0^{\circ}$ longitude (named EG), the other from $0^{\circ}$ longitude to the west coast of Svalbard (named Fram Strait). We also added a section to extend the narrow Bering Strait from $62^{\circ} \mathrm{N}$ to $68^{\circ} \mathrm{N}$ so sufficient grid points can be included in the calculation. According to this definition, a maximum of around 250 to 500 grid points can be extracted from SMAP L3 daily maps with $0.25^{\circ}$ spacing, as listed in Table 3 . The actual number of grid points with valid SSS retrieval changes with time depending on the ice situation, which varies with the gateway. This is illustrated in terms of the percentage of the ice-free area at each gateway (Figure 10, right column). We note that BSO and the Fram Strait are mostly ice-free year round, while EG and the Davis Strait are only open for about three months in summer, with more than $50 \%$ ice cover the rest of the year. The Bering Strait, which is the only gateway connecting the Arctic Ocean and Pacific Ocean, opens about half of the year from June to December. The time series of SSS are obtained by daily averaging over all grid points with valid retrievals at each gateway. In the extremely challenging environment of the Arctic Ocean, we designed two criteria to avoid possible false retrievals. First, we include in the time series calculation only if $>30 \%$ of the grid points are ice-free. The daily mean and standard deviation were obtained from $30 \%$ or more grid points at the gateway with valid SSS data, named $\operatorname{SSS}_{\text {Gateway }}(\mathrm{t})$ and $\delta_{\text {Gateway }}(\mathrm{t})$. Examining the time series, we found extremely large values of $\delta_{\text {Gateway }}(t)$ often occurred at seasonal transitions of ice melting or freezing, suggesting the possibility of undetected ice contamination. Therefore, we defined the second criteria to exclude those outliers. We calculate the standard deviation of $\mathrm{SSS}_{\text {Gateway }}(\mathrm{t})$ over the whole period $\left(\sigma_{\text {Gateway }}\right)$, and defined outliers as those

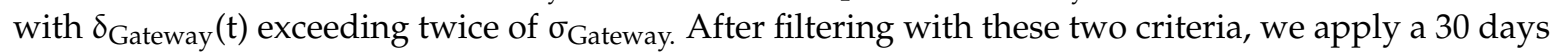
moving average on $\mathrm{SSS}_{\mathrm{Gateway}}(\mathrm{t})$.
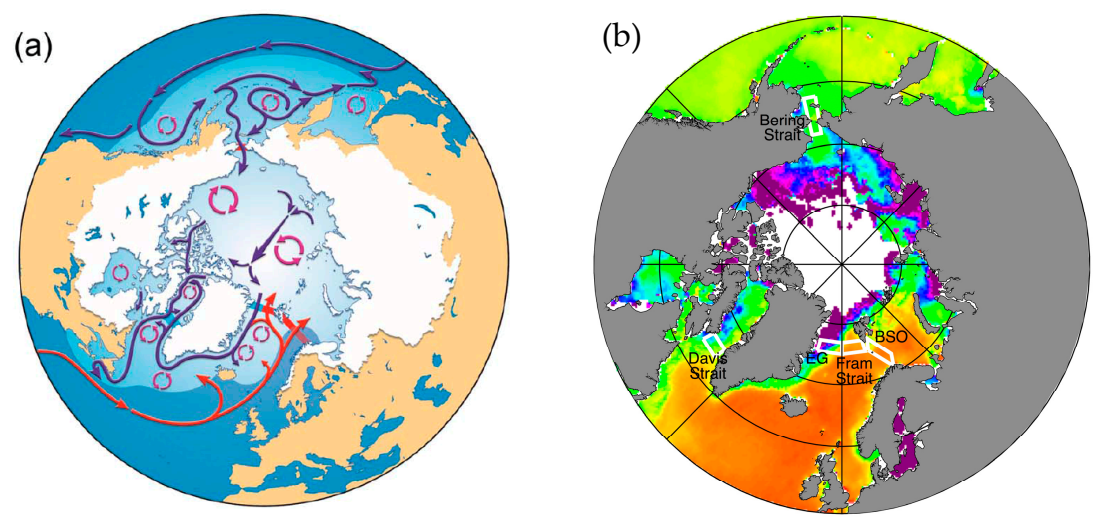

Figure 9. (a) From Carmack et al., 2015 [14]. Schematic maps of the major ocean currents (long arrows), the four Arctic Ocean gateways in Fram Strait, the Barents Sea Opening, Davis Strait, and Bering Strait (thick bars with red denoting inflow and blue denoting outflow), the gyral circulation patterns (circular arrows), the salt-stratified ocean domains are shown in light blue, and the All Arctic Regions definition of the terrestrial contributing areas shown in white. (b) Locations of the Arctic Gateways indicated on SMAP SSS gridded fields (three years mean), which were used in the calculation of mean SSS and the percentage of ice-free area (Figure 10). In this study, the Fram Strait is divided into two parts where currents flow in opposite directions: one between east Greenland coast and $0^{\circ}$ longitude, the other from $0^{\circ}$ longitude to the west coast of Svalbard. Exact coordinates of the four corners of the polygon used for each gateway are given in Table 3. 
Table 3. List of the mean, standard deviation, minimum and maximum values of SMAP SSS retrieved at the Arctic Gateways from 1 May 2015 to 30 April 2018.

\begin{tabular}{|c|c|c|c|c|c|c|}
\hline & & BSO & Fram Strait & E Greenland & Davis Strait & Bering Strait \\
\hline \multirow{4}{*}{ * Gateway location (lon, lat) } & UL & $\left(17^{\circ} \mathrm{E}, 75^{\circ} \mathrm{N}\right)$ & $\left(0^{\circ} \mathrm{E}, 77^{\circ} \mathrm{N}\right)$ & $\left(344^{\circ} \mathrm{E}, 77^{\circ} \mathrm{N}\right)$ & $\left(62^{\circ} \mathrm{W}, 66^{\circ} \mathrm{N}\right)$ & $\left(171^{\circ} \mathrm{W}, 68^{\circ} \mathrm{N}\right)$ \\
\hline & UR & $\left(19^{\circ} \mathrm{E}, 77^{\circ} \mathrm{N}\right)$ & $\left(15^{\circ} \mathrm{E}, 77^{\circ} \mathrm{N}\right)$ & $\left(360^{\circ} \mathrm{E}, 77^{\circ} \mathrm{N}\right)$ & $\left(54^{\circ} \mathrm{W}, 66^{\circ} \mathrm{N}\right)$ & $\left(167^{\circ} \mathrm{W}, 68^{\circ} \mathrm{N}\right)$ \\
\hline & LL & $\left(27^{\circ} \mathrm{E}, 73^{\circ} \mathrm{N}\right)$ & $\left(0^{\circ} \mathrm{E}, 75^{\circ} \mathrm{N}\right)$ & $\left(344^{\circ} \mathrm{E}, 75^{\circ} \mathrm{N}\right)$ & $\left(62^{\circ} \mathrm{W}, 64^{\circ} \mathrm{N}\right)$ & $\left(171^{\circ} \mathrm{W}, 62^{\circ} \mathrm{N}\right)$ \\
\hline & LR & $\left(29^{\circ} \mathrm{E}, 71^{\circ} \mathrm{N}\right)$ & $\left(15^{\circ} \mathrm{E}, 75^{\circ} \mathrm{N}\right)$ & $\left(360^{\circ} \mathrm{E}, 75^{\circ} \mathrm{N}\right)$ & $\left(54^{\circ} \mathrm{W}, 64^{\circ} \mathrm{N}\right)$ & $\left(167^{\circ} \mathrm{W}, 62^{\circ} \mathrm{N}\right)$ \\
\hline \multicolumn{2}{|c|}{ Number of grid points over the gateway } & 512 & 480 & 512 & 256 & 384 \\
\hline \multicolumn{2}{|l|}{ Mean SSS (psu) } & 35.1255 & 34.8499 & 31.2173 & 32.3675 & 31.6195 \\
\hline \multicolumn{2}{|l|}{ SSS Std. (psu) } & 0.3145 & 0.5222 & 2.3011 & 1.0619 & 1.5067 \\
\hline \multicolumn{2}{|l|}{ Min. SSS (psu) } & 33.8045 & 32.6700 & 22.7833 & 29.4338 & 23.4985 \\
\hline \multicolumn{2}{|l|}{ Max. SSS (psu) } & 35.7872 & 35.6629 & 35.0302 & 34.2970 & 33.3319 \\
\hline \multicolumn{2}{|c|}{ Number of valid SSS } & 871 & 1023 & 959 & 660 & 621 \\
\hline
\end{tabular}

* Gateway locations are given in (longitude, latitude) for upper-left (UL), upper-right (UR), low-left (LL), and low-right (LR) corners.

(a) BSO mean SSS

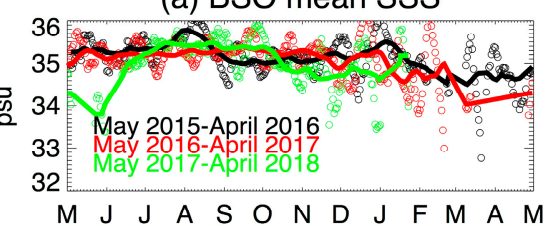

(c) Fram Strait mean SSS

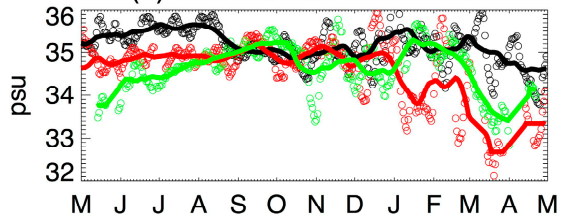

(e) EG mean SSS

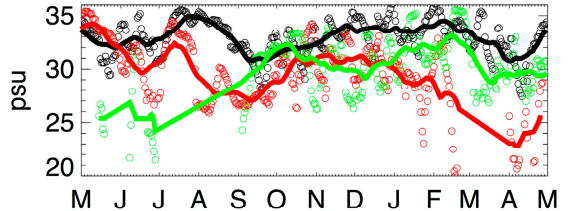

(g) Davis Strait mean SSS

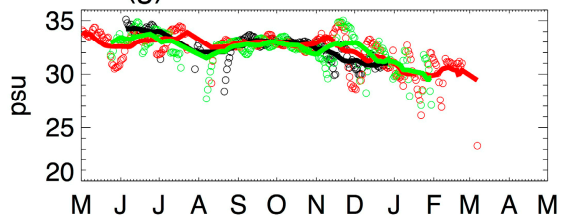

(i) Bering Strait mean SSS

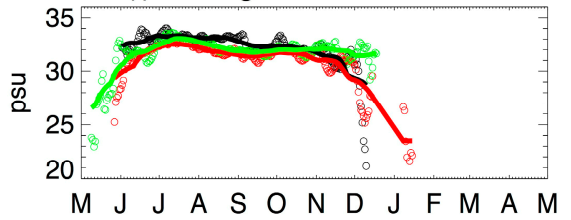

(b) BSO ice-free area

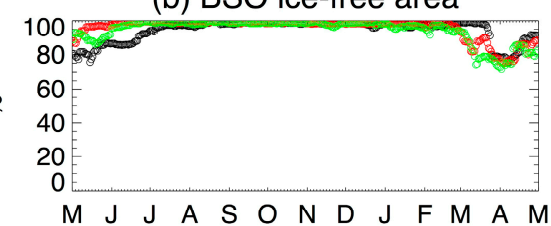

(d) Fram Strait ice-free area

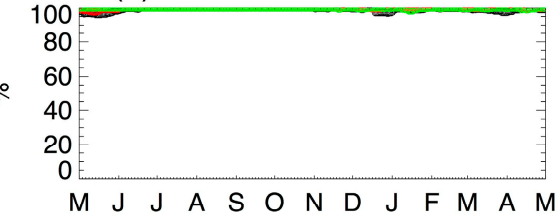

(f) EG ice-free area

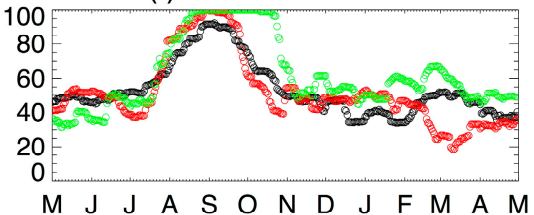

(h) Davis Strait ice-free area

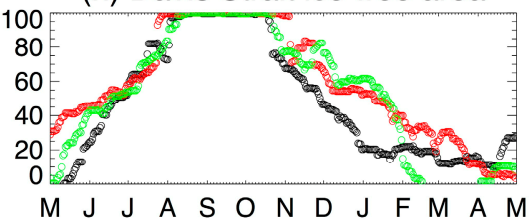

(j) Bering Strait ice-free area

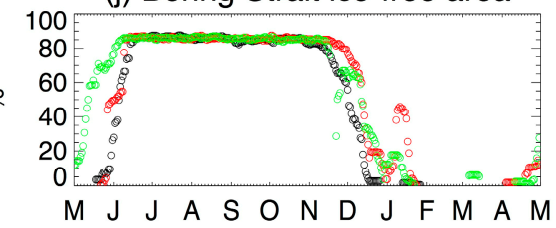

Figure 10. Time series at Arctic Ocean gateways of 1 May 2015-30 April 2016 (black), 1 May 2016-30 April 2017 (red), and 1 May 2017-30 April 2018 (green) of (left) SMAP SSS averaged and (right) percentage of the ice-free area over Arctic gateways defined in Figure 9b. $(\mathbf{a}, \mathbf{b})$ The Barents Sea Opening (BSO); (c,d) the Fram Strait east of $0^{\circ}$ longitude; $(\mathbf{e}, \mathbf{f})$ the Fram Strait opening between east coast of Greenland and Svalbard (EG); (g,h) the Davis Strait; and, $(\mathbf{i}, \mathbf{j})$ the Bering Strait. 30 days moving average is applied on SSS time series (left column, thick lines). 
The time series of SSS at Arctic gateways that were observed by SMAP during the past three summers reveal very rich information (Figure 10, left column). First, it correctly reflects the typical characteristics of the freshwater sources from different ocean basins: relative salty water from the Atlantic and fresh water from the Pacific, with more than 3 psu differences between mean SSS $_{\text {BSO }}$ and

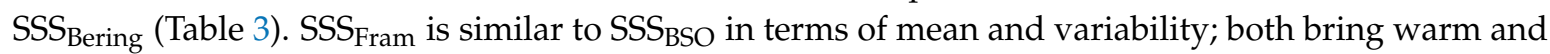
salty Atlantic water into the Arctic Ocean. Also note, SSS $_{\text {Fram }}$ is slightly fresher than SSS $_{\mathrm{BSO}}$, possibility

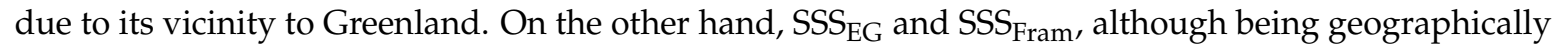
adjacent to each other, bear dramatic contrast in the properties of water transport out from (SSS EG, $_{\text {, }}$

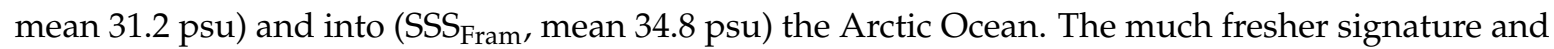
larger dynamical range of SSS $_{\mathrm{EG}}$ suggest the impact of Arctic ice. We note the exceptionally large drop in SSS $_{\text {Fram }}(\sim 3 \mathrm{psu})$ and $\mathrm{SSS}_{\mathrm{EG}}(\sim 6 \mathrm{psu})$ from late 2016 to early 2017. It is unlikely that this large interannual change is caused by the SMAP algorithm or long-term calibration changes because the changes at BSO are much smaller. At this moment, we do not have enough data to pin point the exact mechanism causing such freshening. Also, the magnitude of SSS $_{\mathrm{EG}}$ may need further calibration due to less coverage ( $40 \%$ ice-free area). We speculate that this freshening and recovering in the later part of 2017 is influenced by the Greenland sea ice melting and freezing. This hypothesis may be supported by the observation that the Davis Strait, another passage like EG where outflows of Arctic Ocean modified water mixed with sea ice drift to the northern Atlantic. Different from SSS $\mathrm{EG}_{\text {, }}$ SSS $_{\text {Davis }}$ shows similar seasonal cycles for the three summers that were captured by SMAP.

Consistent seasonal cycles are also observed over the Bering Strait, with a peak-to-peak range of about $4 \mathrm{psu}$. It is also interesting to note the inter-annual difference. SSS $_{\text {Bering }}$ in June-December 2016 (red curve in Figure 10i) is exceptionally low, about 2 psu less than the same period in 2015 (black curve in Figure 10i); while it recovered partially one year later, as seen in Figure 10i, the green curve (June-December 2017) falls between the previous two years. Year 2016 was the strongest El Niño in recent two decades. One well-known characteristic of an El Niño event is the zonal displacement of the western equatorial Pacific warm/fresh pool. The edge of the pool extends eastward during El Niño, retreats westward during La Niña [73-75].

Moorings are installed at all major Arctic Ocean gateways, measuring salinity at depth $\sim 50 \mathrm{~m}$ year round. At the close of this study, we only obtained mooring data at the Bering Strait up to the summer of 2016 [24,69], with about one year overlapping with SMAP data. Figure 11 illustrates the

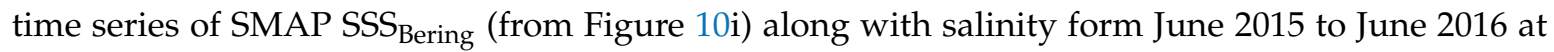
three mooring sites: A2 $\left(66^{\circ} 19^{\prime} \mathrm{N}, 168^{\circ} 57^{\prime} \mathrm{W}\right)$ and $\mathrm{A} 3\left(65^{\circ} 46^{\prime} \mathrm{N}, 168^{\circ} 34^{\prime} \mathrm{W}\right)$ in the US channel of the strait, and A4 $\left(65^{\circ} 44^{\prime} \mathrm{N}, 168^{\circ} 15^{\prime} \mathrm{W}\right)$ close to the Alaskan coast. All three mooring sites are within the white polygon, defined as the Bering Strait (Figure 9b). They are within $90 \mathrm{~km}$ from each other. During August-November, the salinities from the three moorings were mostly within 1 psu from each other, indicating a relatively small spatial variability. However, the A4 mooring data reduced by about 5 psu from November to December, whereas the other two moorings had smaller changes.


accuracy (Section 3.1), and appeared to have a consistent trend with the A4 mooring on the amplitude and timing of the freshening peak in December 2015. Nevertheless, the differences with the other two moorings were clearly larger. A2 and A3 moorings revealed less variability relative to SMAP, which is likely due to the vertical and horizontal dilution from the surface to $50 \mathrm{~m}$ depth. A longer time series of data is required to bring a more definite conclusion on the consistency or discrepancy, possibly resulting from differences in sensing depth or spatial variability. 


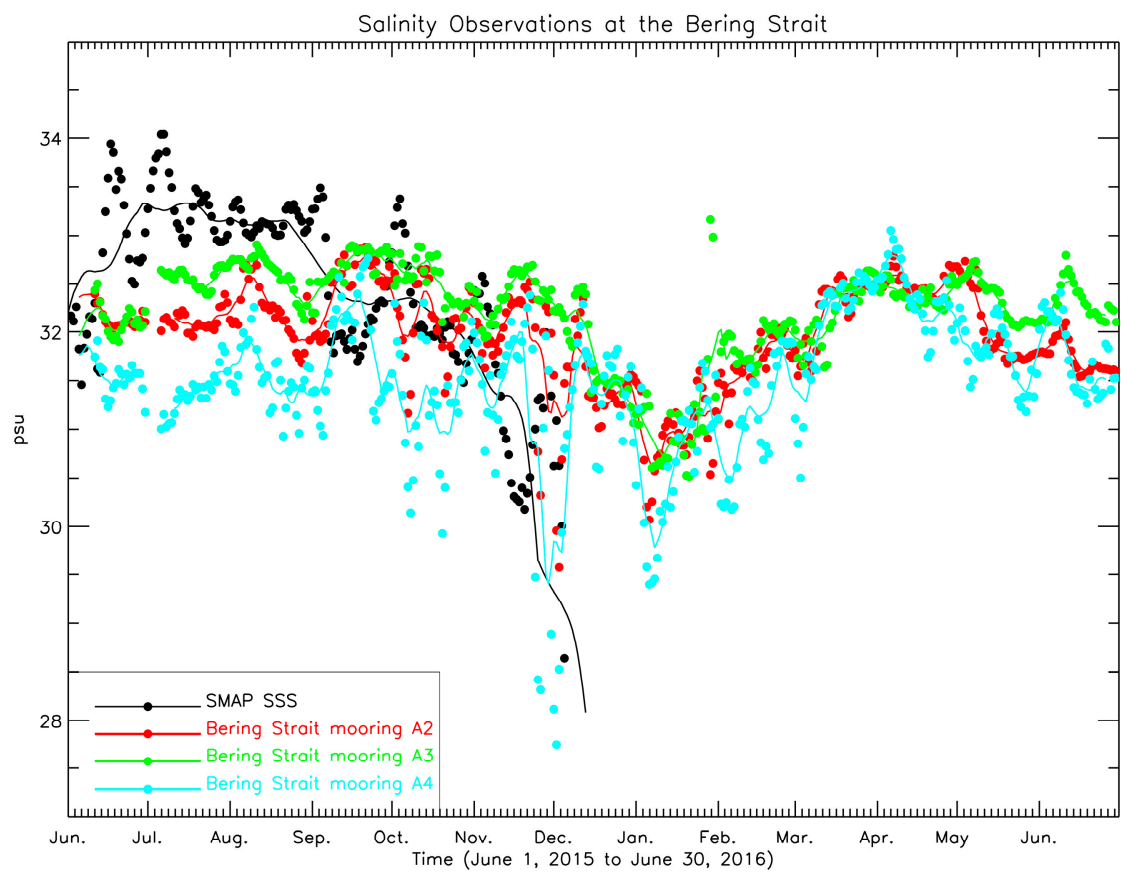

Figure 11. Daily time series of salinity at the Bering Strait retrieved from SMAP (black), and mooring measurement at mooring sites A2 (red), A3 (greed) and A4 (blue). Daily data are indicated by solid dots and lines illustrate the 8 days moving average.

\section{Discussion}

This study explores the utility of SMAP SSS in monitoring the Arctic freshwater system. We emphasize the importance to assess the uncertainty and understanding of the limitations of satellite SSS at this explorative stage in the extremely challenging environment of the Arctic Ocean. We discuss several related issues, including the complementarity of satellite SSS with other satellite and in-situ observations.

First, we point out the urgent need for in situ measurements of salinity in the polar regions to enhance satellite salinity products. Currently, there are very few in situ salinity data available in the areas North of the Arctic Circle (Section 3.1). A sufficiently large database of in situ salinity data (in conjunction with simultaneous geophysical information, such as SST, wind speed and direction, air temperature, and ocean current) will be invaluable. It will not only provide a robust assessment of satellite SSS uncertainties in the Arctic Ocean, but also support the retrieval algorithm refinement, including the SST effect on the roughness correction in cold water.

Second, improved retrievals of sea ice concentration would be of considerable value to reduce possible ice-contaminated SMAP SSS retrievals. It is known that the quality of sea ice concentration product degrades in thin ice, especially at the ice margins and during summer melt. The method of identifying Frazil-pancake ice based on SAR imagery [72] with the wave dispersion technique may have an advantage over passive microwave, as the sea ice concentrations may be quite variable over short time scales [76]. The added information of thickness of this type of young ice [72] will allow quantitative analyses of the SSS response to ice formation and related salt rejection during ice growth on the mixed layer budget.

Third, integrated data analysis is important and necessary to realize the benefit of satellite SSS. One example is using satellite SSS to trace the river discharge. Because satellite observes salinity in the top 1-2 cm of sea surface, SMAP SSS only reveals freshwater variability in the top layer. In stratified regions, SSS alone cannot give the volume of the freshwater distribution, which is traced by satellite from the surface, such as in the Kara Sea (Section 3.3). Quantitative estimation of river discharge impact and distribution over the Arctic Ocean can only be achieved by combining SSS with the salinity 
stratification structure of the upper ocean layer, based on in situ measurements of salinity profiles and ocean circulation models. Another example is the need of ocean currents in estimating freshwater transport. We demonstrated that the SMAP SSS variability could be used to discern the freshwater transport through Arctic Ocean gateways. However, to quantify the freshwater transport that is associated with those SSS variability, one also needs information of the magnitude and direction of ocean currents in addition to salinity profiles.

Finally, we want to emphasize that the value of SMAP SSS relative to data assimilation products, such as HYCOM, cannot be judged from the comparison with co-located in-situ measurements alone. We have shown (e.g., Section 3.3) that SMAP data reveal much stronger interannual variation of SSS than HYCOM. Given HYCOM's relaxation of SSS to seasonal climatology and the use of seasonal climatology of river discharges, SMAP SSS may provide a more reliable dataset to study interannual freshwater changes of the Arctic Ocean in regions where no or few in-situ data are available to constrain HYCOM.

\section{Conclusions}

Here, we demonstrated the potential utility of SMAP SSS in studying Arctic Ocean freshwater changes. The JPL SMAP SSS team adopts an advanced retrieval algorithm near the land and ice edge, aiming to provide the scientific community potentially useful information. We assessed the accuracy of SMAP SSS retrieved North of $50^{\circ} \mathrm{N}$ through comparative analysis with in situ salinity data collected by Argo floats, ships, gliders, and in field campaigns. Results that were derived from near 20,000 pairs collocated within a $12.5-\mathrm{km}$ radius and daily time window indicate a RMSD less than $\sim 1 \mathrm{psu}$ and a correlation coefficient $\sim 0.82$. We have demonstrated the feasibility of using SMAP SSS to study Arctic Ocean salinity response to changes in sea ice concentration and river discharge. In the Arctic Ocean, SMAP SSS reveals seasonal and interannual variations that are consistent with sea ice concentration. In the Kara Sea, the large SSS contrast between 2015 and 2016 observed by SMAP is corroborated by the anomalous freshwater inputs from the $\mathrm{Ob}^{\prime}$ and Yenisey Rivers. We also demonstrated the feasibility to use SSS as a proxy in monitoring the upper layer freshwater exchanges between the Arctic and sub-Arctic Oceans and through the four major Arctic Ocean gateways.

Results presented in this paper may lead to interesting future studies. Particularly, to understand the surface salinity variability that is observed by SMAP at Arctic Gateways, it will be interesting to examine its relation with other variables, such as SST, wind and current, locally and beyond. In conjunction with in situ data, satellite SSS can provide complementary and critical surface information to advance our knowledge on the linkage between the climate changes in polar regions and sub-oceans.

Author Contributions: Data curation, W.T., A.F. and A.H.; Formal analysis, W.T. and S.Y.; Investigation, W.T. and S.Y.; Visualization, W.T.; Writing—original draft, W.T.; Writing—review \& editing, W.T., S.Y., D.Y., A.F., A.H., T.L., S.F. and B.H.

Acknowledgments: This research was carried out at the Jet Propulsion Laboratory, California Institute of Technology, under a contract with the National Aeronautics and Space Administration. Environment and Climate Change Canada provided necessary support to this research collaboration. The SMAP SSS products were provided by the NASA Physical Oceanography Distributed Active and Archive enter (PO.DAAC) at the Jet Propulsion Laboratory. The in situ salinity data were obtained from USGODAE (The US Global Ocean Data Assimilation Experiment), CMEMS (the Copernicus Marine Environment Monitoring Service), and NASA OMG (Ocean Melting Greenland) mission. We also thank Bastien Queste of University of East Anglia, UK for providing the salinity data from seaglider missions. The sea ice concentration data was provided by the National Snow and Ice Data Center (NSIDC). The Arctic river discharge data was provided by the Arctic Great Rivers Observatory at Woods Hole Research Center. The Bering Strait mooring data was provided by the Applied Physics Laboratory at University of Washington. Authors thank the reviewers for their constructive comments and suggestions.

Conflicts of Interest: The authors declare no conflict of interest. 


\section{Abbreviations}

\begin{tabular}{|c|c|}
\hline $\mathrm{AON}$ & Arctic Observing Network \\
\hline APL & Applied Physics Laboratory \\
\hline Arctic-GRO & Arctic Great River Observatory \\
\hline AXCTD & Airborne eXpandable CTD \\
\hline $\mathrm{BSO}$ & The Barents Sea Opening \\
\hline CMEMS & Copernicus Marine Environment Monitoring Service \\
\hline CTD & Conductivity Temperature Depth \\
\hline CONAE & Comision Nacional de Actividades Espaciales \\
\hline ESA & The European Space Agency \\
\hline GOOS & Global Ocean Observing System \\
\hline HYCOM & Hybrid Coordinate Ocean Model \\
\hline INS TAC & In Situ Thematic Assembly Centre \\
\hline JPL & Jet Propulsion Laboratory \\
\hline LUT & look-up-table \\
\hline NASA & The National Aeronautics and Space Administration \\
\hline NCEP & National Centers for Environmental Prediction \\
\hline NRT & near-real-time \\
\hline NSF & The National Science Foundation \\
\hline NSIDC & The National Snow and Ice Data Center \\
\hline OMG & Ocean Melting Greenland \\
\hline PARTNERS & Pan-Arctic River Transport of Nutrients, Organic Matter, and Suspended Sediments \\
\hline PO.DAAC & Physical Oceanography Distributed Active Archive Center \\
\hline RMSD & Root Mean Square Difference \\
\hline ROOS & Regional Ocean Observing System \\
\hline RSS & Remote Sensing System \\
\hline SIC & sea ice concentration \\
\hline SMAP & Soil Moisture Active Passive \\
\hline SMOS & Soil Moisture and Ocean Salinity \\
\hline SSS & sea surface salinity \\
\hline SST & sea surface temperature \\
\hline SWC & salinity-wind-cell \\
\hline $\mathrm{TB}$ & brightness temperature \\
\hline TSG & Thermosalinograph \\
\hline USGODAE & The US Global Ocean Data Assimilation Experiment \\
\hline UTC & The Coordinated Universal Time \\
\hline XCTD & eXpendable CTD \\
\hline
\end{tabular}

\section{References}

1. Kwok, R.; Cunningham, G.F.; Wensnahan, M.; Rigor, I.; Zwally, H.J.; Yi, D. Thinning and volume loss of Arctic sea ice: 2003-2008. J. Geophys. Res. 2009, 114, C07005. [CrossRef]

2. Comiso, J.C. A rapidly decline perennial sea ice cover in the Arctic. Geophys. Res. Lett. 2002, $29,1956$. [CrossRef]

3. Cavalieri, J.D.; Parkinson, C.L. Arctic sea ice variability and trends. 1979-2010. Cryosphere 2012, 6, 881-889. [CrossRef]

4. Proshutinsky, A.; Krishfield, R.; Timmemans, M.-L.; Toole, J.; Carmack, E.; McLaughlin, F.; Williams, W.J.; Zimmermann, S.; Itoh, M.; Shimada, K. The Beaufort Gyre Fresh Water Reservior: State and variability from observations. J. Geophys. Res. 2009, 114, C00A10. [CrossRef]

5. Haine, T.W.N.; Curry, B.; Gerdes, R.; Hansen, E.; Karcher, M.; Lee, C.; Rudels, B.; Spreen, G.; Steur, L.; Stewart, K.D.; et al. Arctic freshwater export: Status, mechanisms, and prospects. Glob. Planet Chang. 2015, 125, 13-35. [CrossRef] 
6. Rage, B.; Karcher, M.; Schauer, U.; Toole, J.; Krishfield, R.; Pisarev, S.; Kauker, F.; Gerdes, R.; Kikuchi, T. An assessment of Arctic Ocean freshwater content changes from the 1990s to 2006-2008. Deep Sea Res. 2011, 58, 173-185. [CrossRef]

7. McLaughlin, F.A.; Carmack, E.C.; Williams, W.J.; Zimmerman, S.; Shimada, K.; Itoh, M. Joint effects of boundary currents and thermo-haline intrusions on the warming of Atlantic water in the Canada Basin, 1993-2007. J. Geophys. Res. 2009, 114, C00A12. [CrossRef]

8. Polyakov, I.V.; Pnyushkov, A.V.; Timokhov, T.A. Warming of the intermediate Atlantic Water of the Arctic Ocean in the 2000s. J. Clim. 2012, 25, 8362-8370. [CrossRef]

9. Rawlins, M.A.; Steele, M.; Holland, M.; Adam, J.; Cherry, J.; Francis, J.; Groisman, P.; Hinzman, L.; Huntington, T.; Kane, D.; et al. Analysis of the Arctic System for Freshwater Cycle Intensification: Observations and Expectations. J. Clim. 2010. [CrossRef]

10. Willis, J.K.; Rignot, E.; Nerem, R.S.; Lindstrom, E. Introduction to the special issue on ocean-ice interaction. Oceanography 2016, 29, 19-21. [CrossRef]

11. Fenty, I.; Willis, J.K.; Khazendar, A.; Dinardo, S.; Forsberg, R.; Fukumori, I.; Holland, D.; Jakobsson, M.; Moller, D.; Morison, J.; et al. Oceans Melting Greenland: Early results from NASA's ocean-ice mission in Greenland. Oceanography 2016, 29, 72-83. [CrossRef]

12. Prowse, T.; Bring, A.; Mård, J.; Carmack, E. Arctic Freshwater Synthesis: Introduction. J. Geophys. Res. Biogeosci. 2015, 120, 2121-2131. [CrossRef]

13. Prowse, T.; Bring, A.; Mård, J.; Carmack, E.; Holland, M.; Instanes, A.; Vihma, T.; Wrona, F.J. Arctic Freshwater Synthesis: Summary of key emerging issues. J. Geophys. Res. Biogeosci. 2015, 120, 1887-1893. [CrossRef]

14. Carmack, C.E.; Yamamoto-Kawai, M.; Haine, T.W.N.; Bacon, S.; Bluhm, B.A.; Lique, C.; Melling, H.; Polyakov, I.V.; Straneo, F.; Timmermans, M.-L. Freshwater and its role in the Arctic Marine System: Sources, disposition, storage, export, and physical and biogeochemical consequences in the Arctic and global oceans. J. Geophys. Res. Biogeosci. 2016, 121. [CrossRef]

15. Lique, C.; Holland, M.M.; Dibike, Y.B.; Lawrence, D.M.; Screen, J.A. Modeling the Arctic freshwater system and its integration in the global system: Lessons learned and future challenges. J. Geophys. Res. Biogeosci. 2016, 121, 540-566. [CrossRef]

16. Thomson, J.; Ackley, S.; Girard-Ardhuin, F.; Ardhuin, F.; Babanin, A.; Boutin, G.; Brozena, J.; Cheng, S.; Collins, C.; Doble, M. Overview of the Arctic Sea State and Boundary Layer Physics Program. J. Geophys. Res. Oceans 2018. [CrossRef]

17. Durack, P.J. Ocean salinity and the global water cycle. Oceanography 2015, 28, 20-31. [CrossRef]

18. Durack, P.J.; Wijffels, S.E.; Matear, R.J. Ocean Salinities Reveal Strong Global Water Cycle Intensification During 1950 to 2000. Science 2012, 336, 455-458. [CrossRef] [PubMed]

19. Schmitt, R.W. Salinity and the global water cycle. Oceanography 2008, 21, 12-19. [CrossRef]

20. Schmitt, R.W. The ocean component of the global water cycle: US National Report to International Union of Geodesy and Geophysics, 1991-1994. Rev. Geophys. 1995, 33 (Suppl. 1), 1395-1409. [CrossRef]

21. Wijffels, S.E.; Schmitt, R.W.; Bryden, H.L.; Stigebrandt, A. On the transport of fresh water by the oceans. J. Phys. Oceanography 1992, 22, 155-162. [CrossRef]

22. Timmermans, M.-L.; Proshutinsky, A.; Golubeva, E.; Jackson, J.M.; Krishfield, R.; McCall, M.; Platov, G.; Toole, J.; Williams, W.; Kikuchi, T.; et al. Mechanisms of Pacific Summer Water variability in the Arctic's Central Canada Basin. J. Geophys. Res. Oceans 2014, 119, 7523-7548. [CrossRef]

23. Timmermans, M.-L.; Proshutinsky, A.; Krishfield, R.A.; Perovich, D.K.; Richter-Menge, J.A.; Stanton, T.P.; Toole, J.M. Surface freshening in the Arctic Ocean's Eurasian Basin: An apparent consequence of recent change in the wind-driven circulation. J. Geophys. Res. 2011, 116, C00D03. [CrossRef]

24. Woodgate, R.A. Increases in the Pacific inflow to the Arctic from 1990 to 2015, and insights into seasonal trends and driving mechanisms from year-round Bering Strait mooring data. Prog. Oceanogr. 2018, 160, 124-154. [CrossRef]

25. Frajka-Williams, E.; Bamber, J.L.; Våge, K. Greenland melt and the Atlantic meridional overturning circulation. Oceanography 2016, 29, 22-33. [CrossRef]

26. Yang, Q.; Dixon, T.H.; Myers, P.G.; Bonin, J.; Chambers, D.; van den Broeke, M.R.; Ribergaard, M.H.; Mortensen, J. Recent increases in Arctic freshwater flux affects Labrador Sea convection and Atlantic overturning circulation. Nat. Commun. 2016, 7, 10525. [CrossRef] [PubMed] 
27. Jackson, L.C.; Kahana, R.; Graham, T.; Ringer, M.A.; Woollings, T.; Mecking, J.V.; Wood, R.A. Global and European climate impacts of a slowdown of the AMOC in a high resolution GCM. Clim. Dyn. 2015, 45, $299-316$. [CrossRef]

28. Leuliette, E.W.; Nerem, R.S. Contributions of Greenland and Antarctica to global and regional sea level change. Oceanography 2016, 29, 154-159. [CrossRef]

29. Agarwal, N.; Köhl, A.; Mechoso, C.R.; Stammer, D. On the early response of the climate system to a meltwater input from Greenland. J. Clim. 2014, 27, 276-296. [CrossRef]

30. Kerr, Y.H.; Waldteufel, P.; Wigneron, J.E.; Delwart, S.; Cabot, F.; Boutin, J.; Escorihuela, M.A.; Font, J.; Reul, N.; Gruhier, C. The SMOS mission: New tool for monitoring key elements of the global water cycle. Proc. IEEE 2010, 98, 666-687. [CrossRef]

31. Font, J.; Camps, A.; Borges, A.; Martin-Neira, M.; Boutin, J.; Reul, N.; Kerr, Y.H.; Hahne, A.; Mecklenburg, S. SMOS: The challenging sea surface salinity measurement from space. Proc. IEEE 2010, 98, 649-665. [CrossRef]

32. Le Vine, D.M.; Lagerloef, G.S.E.; Colomb, F.R.; Yeh, S.H.; Pellerano, F.A. Aquarius: An instrument to monitor sea surface salinity from space. IEEE Trans. Geosci. Remote Sens. 2007, 45, 2040-2050. [CrossRef]

33. Lagerloef, G.; Colomb, F.R.; le Vine, D.; Wentz, F.; Yueh, S.; Ruf, C.; Lilly, J.; Gunn, J.; Chao, Y.; deCharon, A.; et al. The Aquarius/Sac-D Mission: Designed to Meet the Salinity Remote-Sensing Challenge. Oceanography 2008, 21, 68-81. [CrossRef]

34. Yueh, S.H.; Tang, W.; Fore, A.; Neumann, G.; Hayashi, A.; Freedman, A.; Chaubell, J.; Lagerloef, G. L-band Passive and Active Microwave Geophysical Model Functions of Ocean Surface Winds and Applications to Aquarius Retrieval. IEEE Trans. Geosci. Remote Sens. 2013, 51, 4619-4632. [CrossRef]

35. Entekhabi, D.; Njoku, E.G.; O’Neill, P.E.; Kellogg, K.H.; Crow, W.T.; Edelstein, W.N.; Entin, J.K.; Goodman, S.D.; Jackson, T.J.; Johnson, J.; et al. The Soil Moisture Active Passive (SMAP) Mission. Proc. IEEE 2010, 98, 704-716. [CrossRef]

36. Fore, A.; Yueh, S.; Tang, W.; Stiles, B.; Hayashi, A. Combined Active/Passive Retrievals of Ocean Vector Wind and Sea Surface Salinity with SMAP. IEEE Trans. Geosci. Remote Sens. 2016, 54. [CrossRef]

37. Linkages of Salinity with Ocean Circulation, Water Cycle, and Climate Variability. Community White Paper in Response to Request for Information \#1 by the US National Research Council Decadal Survey for Earth Science and Applications from Space 2017-2027. Available online: http:/ / surveygizmoresponseuploads. s3.amazonaws.com/fileuploads/15647/2289356/66-d5c509554e258d30eb31a63804edbf70_LeeTong.docx (accessed on 5 May 2018).

38. Linkages of Salinity with Ocean Circulation, Water Cycle, and Climate Variability. Community White Paper in Response to Request for Information \#2 by the US National Research Council Decadal Survey for Earth Science and Applications from Space 2017-2027. Available online: http:/ / surveygizmoresponseuploads. s3.amazonaws.com/fileuploads/15647/2604456/107-1abc9aa1a37ab7e77d91d86598954a50_LeeTong.pdf (accessed on 5 May 2018).

39. Lang, R.; Zhou, Y.; Utku, C.; le Vine, D. Accurate measurements of the dielectric constant of seawater at L band. Radio Sci. 2016, 51, 2-24. [CrossRef]

40. Klein, L.; Swift, C. An improved model for the dielectric constant of seawater at microwave frequencies. IEEE Trans. Antennas Propag. 1977, 25, 104-111. [CrossRef]

41. Dinnat, E.P.; Brucker, L. Improved sea ice fraction characterization for L-band observations by the aquarius radiometers. IEEE Trans. Geosci. Remote Sens. 2017, 55, 1285-1304. [CrossRef]

42. Brucker, L.; Dinnat, E.P.; Koenig, L.S. Weekly gridded Aquarius L-band radiometer/scatterometer observations and salinity retrievals over the polar regions-Part 1: Product description. Cryosphere 2014, 8, 905-913. [CrossRef]

43. Brucker, L.; Dinnat, E.P.; Koenig, L.S. Weekly gridded Aquarius L-band radiometer/scatterometer observations and salinity retrievals over the polar regions-Part 2: Initial product analysis. Cryosphere 2014, 8, 915-930. [CrossRef]

44. Castro, S.L.; Wick, G.A.; Steele, M. Validation of satellite sea surface temperature analyses in the Beaufort Sea using UpTempO buoys. Remote Sens. Environ. 2016, 187, 458-475. [CrossRef]

45. Garcia-Eidell, C.; Comiso, J.C.; Dinnat, E.; Brucker, L. Satellite observed salinity distributions at high latitudes in the Northern Hemisphere: A comparison of four products. J. Geophys. Res. Oceans 2017, 122, 7717-7736. [CrossRef] 
46. Tang, W.; Yueh, S.H.; Fore, A.G.; Hayashi, A. Validation of Aquarius sea surface salinity with in situ measurements from Argo floats and moored buoys. J. Geophys. Res. Oceans 2014, 119, 6171-6189. [CrossRef]

47. Tang, W.; Fore, A.; Yueh, S.; Lee, T.; Hayashi, A.; Sanchez-Franks, A.; Martinez, J.; King, B.; Baranowski, D. Validating SMAP SSS with in situ measurements. Remote Sens. Environ. 2017, 326-340. [CrossRef]

48. Lee, T. Consistency of Aquarius sea surface salinity with Argo products on various spatial and temporal scales. Geophys. Res. Lett. 2016, 43, 3857-3864. [CrossRef]

49. Boutin, J.; Chao, Y.; Asher, W.E.; Delcroix, T.; Drucker, R.; Drushka, K.; Kolodziejczyk, N.; Lee, T.; Reul, N.; Reverdin, G.; et al. Satellite and in situ Salinity: Understanding Stratification and Sub-Footprint Variability. Bull. Am. Met. Soc. 2016, 97, 1391-1407. [CrossRef]

50. Vinogradova, T.N.; Ponte, R.M. Small-scale variability in sea surface salinity and implications for satellite-derived measurements. J. Atmos. Ocean. Technol. 2018, 30, 2689-2694. [CrossRef]

51. JPL Climate Oceans and Solid Earth Group. JPL SMAP Level 3 CAP Sea Surface Salinity Standard Mapped Image Monthly or 8-Day Running Mean; V4.0 Validated Dataset; PO.DAAC: Pasadena, CA, USA, 2018.

52. NCEP Sea Ice Concentration Analyses. Available online: http://polar.ncep.noaa.gov/seaice/Analyses.shtml (accessed on 5 May 2018).

53. Chassignet, E.P.; Hurlburt, H.E.; Metzger, E.J.; Smedstad, O.M.; Cummings, J.; Halliwell, G.R.; Bleck, R.; Baraille, R.; Wallcraft, A.J.; Lozano, C.; et al. U.S. GODAE: Global Ocean Prediction with the HYbrid Coordinate Ocean Model (HYCOM). Oceanography 2009, 22, 64-75. [CrossRef]

54. Meissner, T.; Wentz, F.J. Remote Sensing Systems SMAP Ocean Surface Salinities [Level 2C, Level 3 Running 8-day, Level 3 Monthly]; Version 2.0 validated release; Remote Sensing Systems: Santa Rosa, CA, USA, 2016.

55. Roemmich, D.; the Argo Steering Team. Argo: The challenge of continuing 10 years of progress. Oceanography 2009, 22, 46-55. [CrossRef]

56. Argo. Argo float data and metadata from Global Data Assembly Centre (Argo GDAC). SEANOE 2000. [CrossRef]

57. European Union Copernicus Marine Environment Monitoring Service (CMEMS). The Arctic Ocean In-Situ Near-Real-Time Observations; Product Identifier INSITU_ARC_NRT_OBSERVATIONS_013_031. Available online: http: / copernicus.eu/situ-thematic-centre-ins-tac/ (accessed on 9 April 2018).

58. OMG Mission. Conductivity, Temperature and Depth (CTD) Data from the Ocean Survey; Version 0.1; OMG SDS: Needham, MA, USA, 2016.

59. Ren, L.; Speer, K.; Chassignet, E.P. The mixed layer salinity budget and sea ice in the Southern Ocean. J. Geophys. Res. 2011, 116, C08031. [CrossRef]

60. Cavalieri, D.J.; Parkinson, C.L.; Gloersen, P.; Zwally, H.J. Sea Ice Concentrations from Nimbus-7 SMMR and DMSP SSM/I-SSMIS Passive Microwave Data, Version 1; [NSIDC-0051]; NASA National Snow and Ice Data Center Distributed Active Archive Center: Boulder, CO, USA, 1996. [CrossRef]

61. Maslanik, J.; Stroeve, J. Near-Real-Time DMSP SSMIS Daily Polar Gridded Sea Ice Concentrations, Version 1; [NSIDC-0081]; NASA National Snow and Ice Data Center Distributed Active Archive Center: Boulder, CO, USA, 1999. [CrossRef]

62. Ye, B.; Yang, D.; Zhang, Z.; Kane, D.L. Variation of hydrological regime with permafrost coverage over Lena Basin in Siberia. J. Geophys. Res. 2009, 114, D07102. [CrossRef]

63. Woo, K.; Kane, D.; Carey, S.; Yang, D. Progress in Permafrost Hydrology in the New Millennium. Permafr. Periglac. Process. 2008, 19, 237-254. [CrossRef]

64. Peterson, B.J.; Holmes, R.M.; McClelland, J.W.; Vorosmarty, C.J.; Lammers, R.B.; Shiklomanov, A.I.; Rahmstorf, S. Increasing river discharge to the Arctic Ocean. Science 2002, 298, 2171-2173. [CrossRef] [PubMed]

65. McClelland, J.W.; Dery, S.J.; Peterson, B.J.; Holmes, R.M.; Wood, E.F. A pan-arctic evaluation of changes in river discharge during the latter half of the 20th century. Geophys. Res. Lett. 2006, 33, L06715. [CrossRef]

66. Arctic Great Rivers Observatory. Discharge Dataset, Version 20180319. 2018. Available online: https: / / www.arcticrivers.org/data (accessed on 19 March 2018).

67. Yang, D.; Ye, B.; Shiklomanov, A. Discharge characteristics and changes over the Ob river watershed in Siberia. J. Hydrometeorol. 2004, 5, 595-610. [CrossRef]

68. Yang, D.; Ye, B.; Kane, D. Streamflow changes over Siberian Yenisei river basin. J. Hydrol. 2004, 296, 59-80. [CrossRef] 
69. Woodgate, R.A.; Stafford, K.M.; Prahl, F.G. A Synthesis of Year-Round Interdisciplinary Mooring Measurements in the Bering Strait (1990-2014) and the RUSALCA Years (2004-2011). Oceanography 2015, 28, 46-67. [CrossRef]

70. De Steur, L.; Hansen, E.; Gerdes, R.; Karcher, M.; Fahrbach, E.; Holfort, J. Freshwater fuxes in the East Greenland Current: A decade of observations. Geophys. Res. Lett. 2009, 36, L23611. [CrossRef]

71. Fournier, S.; Lee, T.; Gierach, M. Seasonal and interannual variations of sea surface salinity associated with the Mississippi River plume observed by SMOS and Aquarius. Remote Sens. Environ. 2016, 180, 431-439. [CrossRef]

72. Wadhams, P.; Aulicino, G.; Parmiggiani, F.; Persson, P.O.G.; Holt, B. Pancake ice thickness mapping in the Beaufort Sea from wave dispersion observed in SAR imagery. J. Geophys. Res. Oceans 2018, 123. [CrossRef]

73. Jin, F.F. An equatorial ocean recharge paradigm for ENSO. Part I: Conceptual model. J. Atmos. Sci. 1997, 54, 811-829. [CrossRef]

74. Picaut, J.; Masia, F.; Penhoat, Y.D. An advective-reflective conceptual model for the oscillatory nature of the ENSO. J. Geophys. Res. 1997, 103, 14261-14290. [CrossRef]

75. Qu, T.; Yu, J.Y. ENSO indices from sea surface salinity observed by Aquarius and Argo. J. Oceanogr. 2014, 70, 367-375. [CrossRef]

76. Steele, M.; Ermold, W. Loitering of the retreating sea ice edge in thearctic seas. J. Geophys. Res. Oceans 2015, 120, 7699-7721. [CrossRef] [PubMed]

(C) 2018 by the authors. Licensee MDPI, Basel, Switzerland. This article is an open access article distributed under the terms and conditions of the Creative Commons Attribution (CC BY) license (http:/ / creativecommons.org/licenses/by/4.0/). 